Rhode Island College

Digital Commons @ RIC

Master's Theses, Dissertations, Graduate

Master's Theses, Dissertations, Graduate Research and Major Papers Overview

Research and Major Papers

$11-24-2020$

\title{
Comparing Recovery Times of Desflurane and Sevoflurane
}

Gina M. Stangel

Follow this and additional works at: https://digitalcommons.ric.edu/etd

Part of the Nursing Commons

\section{Recommended Citation}

Stangel, Gina M., "Comparing Recovery Times of Desflurane and Sevoflurane" (2020). Master's Theses, Dissertations, Graduate Research and Major Papers Overview. 370.

https://digitalcommons.ric.edu/etd/370

This Major Paper is brought to you for free and open access by the Master's Theses, Dissertations, Graduate Research and Major Papers at Digital Commons @ RIC. It has been accepted for inclusion in Master's Theses, Dissertations, Graduate Research and Major Papers Overview by an authorized administrator of Digital Commons @ RIC. For more information, please contact digitalcommons@ric.edu. 
COMPARING THE RECOVERY TIME BETWEEN DESFLURANE AND

SEVOFLURANE: A SYSTEMATIC REVIEW

\author{
A Major Paper Submitted in Partial Fulfillment \\ of the Requirements for the Degree of \\ Master of Science in Nursing \\ by \\ Gina Marie Stangel \\ in
}

The School of Nursing

Rhode Island College

2020 


\begin{abstract}
General anesthesia is intended to deliver proper comfort and pain relief, with a safe and rapid recovery with minimal side effects. Ideally, patients are optimized prior to undergoing anesthesia, (an asthmatic receiving an albuterol treatment to reduce the likelihood of bronchospasm, for example). Emergence from anesthesia involves the reversal of a neuromuscular blockade if used, a patient breathing spontaneously, regaining consciousness, and the ability to follow commands. Patients requiring general anesthesia can be given intravenous propofol, an inhaled anesthetic gas or a combination of both. Volatile anesthetic gases used today allow for rapid recovery from anesthesia due to their low-blood gas solubility. While volatiles are generally safe for patients, inhalation agents do cause respiratory depression, which can still pose a problem once the patient is transferred to the post-anesthesia care unit (PACU). Respiratory depression has the potential to cause atelectasis, hypoxia, hypercarbia, and longer PACU or hospital stays. General anesthesia also results in the loss of protective airway reflexes, which can lead to pulmonary aspiration and potentially cause pneumonia and death. Sevoflurane and desflurane are two of the most commonly used volatile anesthetics in the United States. The purpose of this systematic review was to compare the recovery time between desflurane and sevoflurane in hospitalized adults undergoing general anesthesia. The PRISMA flow diagram was used to guide the systematic review. Data was collected from each study and a cross study analysis was conducted. Findings indicated, in all studies, that desflurane showed significantly faster recovery than sevoflurane. Use of desflurane over sevoflurane shows faster, safer recovery, an important consideration for anesthesia providers. Applying this to practice can make an immense difference in the post-operative recovery of adults undergoing general anesthesia.
\end{abstract}




\section{Acknowledgements}

I would like to thank my beautiful daughters, Aislyn and Lanna Stangel. The two of you have given me the strength and motivation to always do more and be more, for

you. Aislyn, I became a nurse because of everything you experienced as an infant. Your ICU nurses amazed me and I wanted to do for others what they were able to do for our family and for you. Lanna, I decided to go back to school to be a nurse when you were a baby so that I would always be able to provide for you. Girls, I knew that going back to school to be a CRNA would not be easy for our little family, but I want you to know it was all done for you. I am sorry I have not been there as much as you both may want or need, but please know this was all for you. I always want to be able to take care of you. Both of you continue to amaze me and allow me to keep striving to make our lives better. I love you more than you know. This is all for you. 


\section{Table of Contents}

Background/Statement of the Problem ...........................................

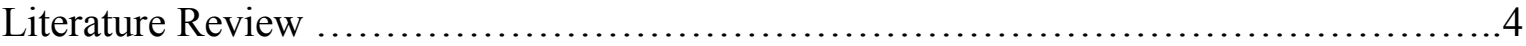

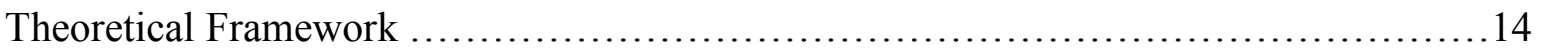

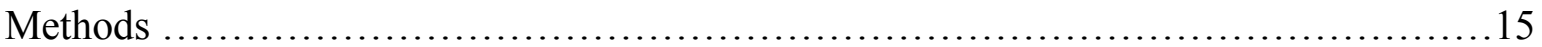

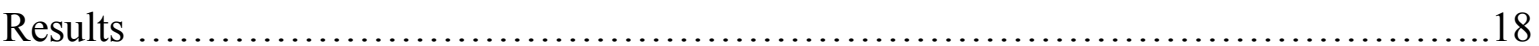

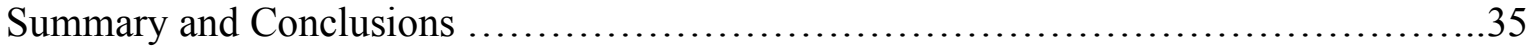

Recommendations and Implications for Advanced Nursing Practice ....................39

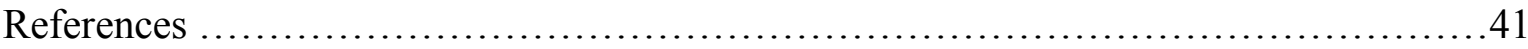

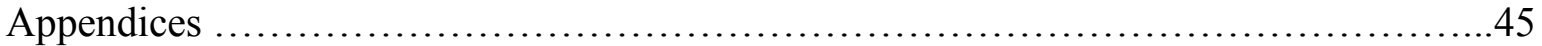


Comparing the Recovery Time Between Desflurane and Sevoflurane: A Systematic

Review

\section{Background/Statement of the Problem}

Inhalation gasses are used in combination with other medication to ensure analgesia, amnesia, anesthesia, and muscle relaxation (or paralysis) during surgical procedures. Inhalation gasses are commonly used to produce loss of consciousness, while avoiding an unpleasant induction and ensuring rapid recovery for the best possible outcome. Although the use of inhalation agents began as early as the 1840 's, there is still much unknown about the exact mechanism of action on the human brain.

Modern anesthesia gasses consist of three volatile agents: isoflurane, sevoflurane, and desflurane, and a non-volatile agent, nitrous oxide. These gasses are administered in combination with oxygen or room air to achieve a sleep like state while providing patients with enough oxygen so that tissue damage does not occur. The three volatile agents are halogenated, where a halogen atom is substituted for one or more hydrogen atoms which influences their "anesthetic potency, arrhythmogenic properties, flammability, and chemical stability" (Nagelhout \& Plaus, 2014, p. 85). The volatile agents also need to be vaporized, from a liquid to gas state prior to being administrated to the patient, as to not overdose them.

The minimum alveolar concentration (MAC) of an anesthetic gas is its dose; the term 'MAC' is used in lieu of the term dose. The MAC values among the gasses are the minimum required for immobility (Nagelhout \& Plaus, 2014). While most medication dosing commonly administered to patients are based on the ED 99 (or the effective dose for $99 \%$ of the population), anesthetic gasses are based on the ED 50 (or the effective dose for $50 \%$ of the population) because they have a synergistic relationship with a 
variety of other drugs that are used for anesthesia (opioids, benzodiazepines, and sedative-hypnotics). The potency of the anesthetic is directly related to the lipid solubility, so the more lipid soluble, the more potent. The more potent the anesthetic the less the MAC value will be. Sevoflurane's MAC value is $2 \%$, while desflurane's is $5.8 \%$. While the three volatile agents available today are often used interchangeably among anesthesia providers, there are differences among the gasses. For example, desflurane is more pungent than the other gasses and tends to cause more tachycardia. All three of the volatile agents tend to decrease blood pressure, cause central nervous system depression, cardiac depression, and bronchodilation. Depending on the healthcare facility, providers may only have one or two of the three volatile agents available to administer.

Time to anesthesia and recovery from anesthetic gas is related to the blood/gas solubility of the agent, or its blood solubility. The more plasma soluble the drug, the slower the uptake to the brain and the slower the recovery from anesthesia. Sevoflurane's blood/gas partition coefficient is 0.6 . The blood/gas partition coefficient of desflurane is 0.42 , which means only 0.42 of a molecule remains in the blood for every one molecule that enters tissues, so anesthesia and recovery from anesthesia is achieved more quickly than with sevoflurane, due to the molecules being eliminated from the blood stream at a faster rate (Nagelhout \& Plaus, 2014). Rapid emergence from anesthesia promotes the patient's ability to breathe independently and protect the airway, allowing for safer extubation. Anesthetic gas choice can result in differences among airway reflexes and neurological exams, affecting their Aldrete score (Appendix A), a 
scale used to determine when a patient can be safely discharged from the Post Anesthesia Recovery Unit (PACU).

Therefore, the purpose of this paper is to present a systematic review to compare the recovery time between desflurane and sevoflurane in hospitalized adults undergoing general anesthesia. 


\section{Literature Review}

To search literature on this topic, the key words searched were desflurane, sevoflurane, recovery, emergence, and anesthesia. Databases used were Medline, PubMed, and Google Scholar. Key words were searched separately and combined to produce results. The time period originally searched was from 2014 to 2019 . This time period was expanded to 1995 to examine relevant literature in adults.

\section{Definition of Anesthesia}

"Anesthesia" is "a change in the responses of an intact animal to external stimuli" (Barash et al., 2012, p. 108). "The practice of anesthesia requires a full spectrum of drugs from which an anesthetic plan can be implemented to achieve the desired level of surgical anesthesia, analgesia, amnesia, and muscle relaxation" (Nagelhout, 2014, p. 53). Before the hypodermic needle was invented in 1855, anesthesia providers used inhalation agents as the sole general anesthetic (Butterworth, Mackey, \& Wasnick, 2013). Inhalation agents such as nitrous oxide, isoflurane, desflurane, sevoflurane, and in some locations, halothane continue to be used in clinical anesthesiology currently (Butterworth et al., 2013). General anesthesia is divided into three phases: induction, maintenance, and emergence (Butterworth et al., 2013). Induction is when a patient is considered unconscious at the beginning of anesthesia (Nagelhout \& Plaus, 2014). Maintenance of anesthesia can be described as sustaining hemodynamic stability and the desired depth of anesthesia for the specific procedure and patient (Nagelhout \& Plaus, 2014). Emergence is the patient awakening from general anesthesia at the end of the surgical procedure (Nagelhout \& Plaus, 2014). Inhalation agents have unique useful properties that are different than other anesthetic medications. For example, inhalation administration via 
the pulmonary circuit results in a more rapid uptake into the bloodstream than intravenous administration (Butterworth et al., 2013).

\section{Inhalation Anesthetics}

The exact mechanism of action of inhalation anesthetics is extremely complex and is not fully understood. It is known that the mechanism of action involves membrane proteins and ion channels which leads to a therapeutic level in the central nervous system (CNS) (Butterworth et al., 2013). To produce an adequate anesthetic state with inhalation anesthetics, a specific concentration of anesthetic molecules must be established in the CNS. Anesthesia providers monitor the partial pressure of anesthetic agents in the lungs, which represents the partial pressures in both the brain and spinal cord (Barash et al., 2012). The pharmacokinetics of inhaled anesthetics describe their uptake, distribution, metabolism, and elimination. The uptake is defined as the absorption from alveoli into the pulmonary capillary blood. Distribution is the drug's movement throughout the body and metabolism is how the body breaks down the drug. Anesthetic gasses have a very small amount of metabolism; most of the drug is eliminated. Elimination of the inhaled anesthetic is primarily by the lungs "breathing off" the gas. Volatile gasses are delivered to the patient from the anesthesia machine by traveling into the patient's lungs, then into arterial blood and to the brain. The gasses leave the patient's brain, enter into venous blood, travel back to the lungs, and travel outwards though the breathing circuit. The monitor shows the anesthesia provider the amount of gas inhaled and exhaled by the patient throughout the procedure. To induce anesthesia faster at the start of a surgical procedure, providers can hyperventilate a patient to increase the rate of inhalation and thus increase the rate of induction or use the concentration effect by using a higher 
concentration of the gas to act as a loading dose to speed the initial uptake, by increasing the MAC up front. A patient's cardiac output also affects the rate of induction; a higher cardiac output slows the rate of induction, while a lower cardiac output increases the rate of induction. Right to left shunts will also slow the rate of induction of anesthesia because blood leaving the lungs with anesthetic dissolved is being diluted with blood coming from the right side of the heart. A volatile gas' blood gas solubility also has an effect on the rate of induction and the rate of recovery from anesthesia. The blood gas coefficient expresses the solubility of an anesthetic agent. It is the ratio of an anesthetic in the blood phase to the concentration in the gas phase (Eger, 2004). The more blood soluble the gas, the slower the brain and spinal cord uptake, which results in slower anesthetic induction. The less blood soluble the gas, the faster the gas leaves the blood and enters tissues, resulting in rapid induction of anesthesia.

The MAC of an anesthetic gas is essentially another term for its "dose". The ED50, or effective dose to cause immobility in $50 \%$ of the population, is used for the MAC of anesthetic gasses (Nagelhout \& Plaus, 2014). Most medications administered to patients are based on the ED99, or effective dose for $99 \%$ of the population, but all anesthetics used together have a synergistic relationship, so the ED50 is used, as to not over anesthetize patients. A strategic combination of anesthetic drugs is used to achieve anesthesia, analgesia, amnesia, and when necessary muscle relaxation (Nagelhout \& Plaus, 2014). It is important to remember that MAC value changes with age, like required doses of numerous medications. All volatile anesthetics cause dose-dependent myocardial depression and a decrease in mean arterial pressure (MAP) with increased concentrations due to decreased systemic vascular resistance (SVR) (Nagelhout \& Plaus, 
2014). MAP can be defined as the average pressure in the arteries during a cardiac cycle (Nagelhout \& Plaus, 2014). It can be calculated by doubling the diastolic pressure and adding that to the systolic pressure and dividing by three (Nagelhout \& Plaus, 2014). Patients become hypotensive due to the vasodilation and bradycardic because of the depressed myocardium, but, cardiac Index (CI) is only minimally influence by volatile anesthetics (Nagelhout \& Plaus, 2014). Cardiac Index is a patient's cardiac output while taking into consideration their body mass index (BMI). Cardiac output can be calculated by multiplying heart rate times stroke volume, the amount of blood the heart pumps out in each beat. (Nagelhout \& Plaus, 2014).

\section{Desflurane}

Desflurane, a volatile gas that was introduced in 1993, has a blood: gas solubility of 0.45 , leading to a faster onset and emergence of anesthesia (Nagelhout \& Plaus, 2014). The MAC for an adult 33-35 years of age is $6.6 \%$. There is minimal metabolism with desflurane due to its vapor pressure being almost that of atmospheric pressure at 669 $\mathrm{mmHg}$. Desflurane is costly and requires a "heated, pressurized vaporizer requiring electrical power to deliver a regulated concentration of desflurane as a gas" (Barash et al., 2012, p. 457). Desflurane can cause hypertension, tachycardia, dose-dependent vasodilation, and is a known respiratory irritant. It is the most pungent of the volatile anesthetics and if administered via facemask can lead to laryngospasm (Barash et al., 2012). Because of the unpleasant odor and potential for laryngospasm, desflurane is typically not used for inhalation inductions. Inhalation inductions are often administered in pediatrics and patients who are unable to tolerate an intravenous line (IV) insertion 
while they are awake. Desflurane can be and is administered after the patient is anesthetized via IV induction agents, to maintain a suitable level of anesthesia.

\section{Sevoflurane}

Sevoflurane was approved for use by the Food and Drug Administration (FDA) in 1995 (Nagelhout \& Plaus, 2014). While sevoflurane also has a low blood gas solubility, it is higher than that of desflurane at 0.65 , making it slower than desflurane for induction and emergence from anesthesia. Unlike desflurane, it has a sweet smell and is not pungent. There is lack of bronchial irritation with sevoflurane and it a great choice for asthmatics and inhalation induction for pediatrics. Pediatric patients are not typically tolerant of having IV catheters placed while awake, so anesthesia providers use volatile anesthetics to induce anesthesia. Sevoflurane is both a skeletal and smooth muscle relaxant and the vapor pressure is much lower than desflurane, so a basic vaporizer can be used. Sevoflurane has a slightly higher metabolism than the other volatile gasses, at about $2-5 \%$, which can theoretically produce inorganic fluoride, potentially harming kidney function. However, according to Barash et al. (2012), sevoflurane has not been associated with inhibiting kidney function. While all volatile gasses can produce carbon monoxide, and the greatest effect is with desflurane, sevoflurane has the ability to produce Compound $\mathrm{A}$. Compound $\mathrm{A}$ is a byproduct of the chemical reaction between the gas and desiccated carbon dioxide absorbents, which led to renal toxicity in rats. Fresh gas flows around two liters per minute are administered to prevent the accumulation of Compound A. 


\section{Recovery after Anesthesia}

According to Nagelhout \& Plaus (2014), post-anesthesia recovery's purpose is critical assessment, recognition, and stabilization of patients after surgical procedures where sedation, analgesia, and/or anesthesia has been administered. Complications need to be detected immediately. After the patient's vital signs have been assessed and the patient is stable, the anesthesia provider communicates relevant information to the PACU nurse. To assess patients in the PACU, the Aldrete Score is commonly used, which allows the providers to evaluate activity, respirations, circulation, consciousness, and oxygen saturation. Patients' discharge from PACU might be to home, a surgical floor, or intensive care unit depending on their postoperative status and level of functioning. Prior to discharge, respiratory status must be appropriate. Airway reflexes and motor function needs to be fully intact to prevent aspiration (Nagelhout \& Plaus, 2014). Nagelhout and Plaus (2014) state that in order to discharge a patient from PACU, they need a regular respiratory pattern and rate, no restlessness or confusion, vital signs within normal limits for that specific patient, the ability to maintain a patent airway, and surgical stability of the operative site.

\section{Complications of Inhalation Anesthetics}

Only a small number of studies have explored the effects of inhalation anesthetics and postoperative cognitive outcomes, despite these anesthetics being widely used in anesthesia today (Barash et al., 2012). Patients experiencing delayed awakenings are a major concern in the perioperative period. The time to emerge from anesthesia is affected by numerous factors such as the specific patient, anesthesia administered, and duration of the procedure. Pharmacological agents are particularly responsible for 
delayed awakenings after the completion of a procedure (Misal, Joshi, \& Shaikh, 2016).

Recovery from anesthesia can be divided into three phases: immediate recovery, intermediate recovery, and long-term recovery (Misal et al., 2016). Immediate recovery can be defined as a patient breathing on their own, return of consciousness, intact airway reflexes to avoid aspiration, and regaining motor activity (Misal et al. 2016). Without protective airway reflexes intact, a patient is at risk for aspiration due to their inability to cough and swallow. During the intermediate recovery phase, the patient will regain motor coordination. This is the point where a patient may be considered for discharge from the PACU (Misal et al., 2016). A patient not fully recovered from anesthesia may require re-intubation in order to protect their airway. Many factors contribute to the necessary intervention of re-intubating a patient in the PACU: chronic pulmonary disease, preoperative hypoalbuminemia, creatinine clearance, being an emergent case, operative time over three hours, airway surgery, head and neck surgery, cardiac or thoracic surgery, cardiac catheterization, ASA physical status III or higher, and the use of neuromuscular blocking agents (Rukirojindakul et al., 2012).

Post-anesthesia care and quality consists of numerous factors such as the tracking of complications, time spent in recovery, overall clinical outcomes, and patient satisfaction (Barash et al., 2012). Many serious complications following the administration of anesthesia may arise. Cardiovascular and pulmonary complications may arise in the post-operative period. Myocardial ischemia can present itself in patients with coronary artery disease. Hypertension and dysrhythmias might also occur in the post-operative period. Pulmonary complications can occur because ventilation, oxygenation, and airway maintenance are impaired while under anesthesia. (Barash et 
al., 2012). Airway obstruction due to the tongue occluding the pharynx or laryngospasm can interfere with oxygen and ventilation (Nagelhout \& Plaus, 2014). Other respiratory complications are hypoxemia, pulmonary edema, atelectasis, pulmonary embolism, aspiration, bronchospasm, and hypoventilation (Nagelhout \& Plaus, 2014).

Immediately after anesthesia, residual effects of both IV and inhalation anesthetics blunt the normal ventilatory responses to hypercarbia (higher levels of carbon dioxide) and hypoxemia (lower levels of oxygen) (Barash et al., 2012).

Patients that are paralyzed for surgical procedures that might be inadequately reversed can hypoventilate or obstruct their airways. Emergence delirium, which can appear as fear, agitation, and disturbances in attention, orientation and intellectual function, can occur in certain patients. Hypoxemia must be ruled out as the cause of delirium. Delayed awakening, while often times inconvenient for providers, patients, and families, is usually not a serious complication. An individual may take longer to awaken due to the prolonged action of anesthetics, metabolic causes, and neurologic injury (Nagelhout \& Plaus, 2014). Age, hypothermia, alcohol and drug use, potentiation of effects of anesthetics used, and hypoventilation can contribute to delayed awakening (Nagelhour \& Plaus, 2014). A computed tomography (CT) scan may be warranted if all other possible causes of delayed awakening are ruled out (Nagelhout \& Plaus, 2014).

\section{Time to recovery for Desflurane and Sevoflurane}

While no current inhalation anesthetics used at this time possesses every property of an ideal inhalation agent, desflurane and sevoflurane both have a number of clinical benefits making them routinely used for surgical procedures (Nagelhout \& Plaus, 2014). Based on the blood gas partition coefficient, desflurane, in theory should yield faster 
emergence and recovery than sevoflurane. In a retrospective study by Kim, Lee, Lee, and Koo (2013), the authors sought out to determine which agents prompted less recovery time in pediatric patients, after undergoing minor surgery. The authors examined the timing of self-respiration, eye opening after verbal command, and extubation. Times were significantly faster in the desflurane group than in the sevoflurane group. Times to self-respiration were 4.6 minutes in the desflurane group verses sevoflurane at 6.9 minutes. Times to eye opening on verbal command for desflurane was 6.6 minutes verses 9.2 minutes for sevoflurane and time to extubation for desflurane was 6.2 minutes and 9.3 minutes for sevoflurane. According to the authors, no significant statistical differences were found perioperatively regarding adverse respiratory events (Kim et. al., 2013).

Wu et al. (2019) performed a retrospective study in children comparing desflurane and sevoflurane and the postoperative recovery after tonsillectomy and adenoidectomy. The sevoflurane group had longer operation time, anesthesia time, and extubation time than those in the desflurane group (Wu et al., 2019). Ramsay and Pediatric Anesthesia Emergence Delerium (PAED) scores were used to compare the two groups. Children in the sevoflurane group had lower Ramsay scores and higher PAED scores than the children in the desflurane group 10 and 30 minutes after extubation. This study found that desflurane was a safer and more effective anesthetic to administer. The Ramsay sedation score can be seen in Appendix B. The Pediatric Anesthesia Emergence Delirium (PAED) scale can be seen in Appendix C.

A study conducted by Nathanson, Fredman, Smith, \& White (1995) examined the recovery of desflurane compared to sevoflurane in 42 women undergoing outpatient 
anesthesia. Faster emergence, (4.8 minutes verses 7.8 minutes) and faster extubation times, (5.1 minutes verses 8.2 minutes) were seen in the desflurane group, but recovery and discharge times were similar among the two groups. 


\section{Theoretical Framework}

"A framework is the overall conceptual underpinnings of a study." (Polit \& Beck, 2017, p. 119) Systematic reviews are often used to guide healthcare professionals' decision-making (Moher et al., 2009). These reviews allow providers to create guidelines and follow evidence-based practice. The Preferred Reporting Items for Systematic Review and Meta-Analysis Protocols (PRISMA-P) has been developed to aide in crucial reporting. PRISMA consists of a checklist and flow diagram. The PRISMA checklist includes a list of 27 items consisting of eligibility criteria, study selection, data collection process, and risk of bias to evaluate healthcare interventions (Appendix D). The purpose of this checklist it to ensure transparency of published studies. It establishes the minimum criteria required for the evidence-based studies within a systematic review (Moher et al., 2019). The PRISMA flow diagram (Appendix E) provides a detailed account of each RCT utilized in the systematic review and why it was chosen. This diagram is meant to portray the flow of information through the different segments of a systematic review or meta-analysis. It allows the author to identify the number of fulltext articles assessed for eligibility, those excluded, and studies in the qualitative synthesis. The PRISMA checklist and flow diagram provide the theoretical framework for this systematic review. 


\section{Methods}

\section{Purpose}

The purpose of this paper is to present a systematic review to compare the recovery time between desflurane and sevoflurane in hospitalized adults undergoing general anesthesia.

\section{Inclusion and Exclusion Criteria}

Inclusion criteria consisted of RCTs which included all of the following: adult patients 18 years and older undergoing a surgical procedure requiring general anesthesia with endotracheal intubation, categorized by the American Society of Anesthesiologists (ASA) physical status of I, II, and III, and received sevoflurane or desflurane volatile anesthetics. Only studies that were published within the last five years were included.

Exclusion criteria included ASA physical status IV, V, or VI, use of total intravenous general anesthesia (TIVA), patients less than 18 years old, and RCTs older than five years.

\section{Search Strategy}

Databases used were Medline, CINAHL, and PubMed. Key words searched were "Desflurane", "Sevoflurane", "Recovery", and "Anesthesia." Key words were searched separately and combined to produce results. The time period searched was from 2014 to 2019.

\section{Data Collection}

In order to adequately establish recovery time of the two volatile gasses, the following table was used. Data from each study was entered into table format to provide organization for the author. Table 1 consists of identifying the purpose of the study, 
location site, sample, and design method. Table 2 consists of the type of surgical procedure, recovery scale or recovery method used, the results, and limitations. Within the results column, sevoflurane and desflurane groups were compared, using the authors' recovery scale.

$\underline{\text { Table } 1}$ - Data Collection Tool 1

\begin{tabular}{|l|l|l|l|}
\hline Purpose & Setting & Sample & Design Method \\
\hline & & & \\
& & & \\
\hline
\end{tabular}

\section{$\underline{\text { Table } 2}$}

\begin{tabular}{|l|l|l|l|}
\hline $\begin{array}{l}\text { Type of Surgical } \\
\text { Procedure }\end{array}$ & $\begin{array}{l}\text { Recovery Scale } \\
\text { Used }\end{array}$ & Results & Limitations \\
\hline & & & \\
& & & \\
\hline
\end{tabular}

\section{Critical Appraisal Tools}

For any research study or systematic review to be trusted by healthcare professionals, they need to be critically appraised. Data presented to clinicians must be accurate and reliable because the health and well-being of patients depend on professionals' ability to make educated decisions. The use of evidence-based practice is crucial in making decisions about patient care. The appraisal instrument that was used for this systematic review is the Critical Appraisal Skills Programme (CASP). CASP summarizes evidence by answering 11 yes or no questions for each randomized control 
study. Questions to be answered include whether or not the assignment of patients was randomized, if the groups were treated equally, and whether or not the benefits were worth the harms and costs. If the appraiser is unable to answer a question, there is an option to choose that states "can't tell". The CASP checklist for randomized controlled trials can be found in Appendix F.

\section{Cross Analysis}

Once the data has been organized into the data collection tables, and critically appraised, a cross analysis of the RCTs was conducted to compare the similarities and differences between the studies. The cross study analysis data is organized into a table and identifies the author, type of surgical procedure, method used to measure recovery time, and the time to recovery of both desflurane and sevoflurane (Table 2).

Table 2 - Cross Study Analysis

\begin{tabular}{|c|c|c|c|c|}
\hline Author & $\begin{array}{c}\text { Type of Surgical } \\
\text { Procedure }\end{array}$ & $\begin{array}{c}\text { Method used } \\
\text { to Measure } \\
\text { Recovery } \\
\text { Time }\end{array}$ & $\begin{array}{c}\text { Time to Recovery } \\
\text { with Desflurane }\end{array}$ & $\begin{array}{c}\text { Time to } \\
\text { Recovery with } \\
\text { Sevoflurane }\end{array}$ \\
\hline & & & & \\
\hline
\end{tabular}




\section{Results}

\section{Data collection}

Multiple databases were used to identify pertinent RCTs utilized in this systematic review. The PRISMA flow diagram was employed to establish a search for appropriate literature. Databases used were Cochrane, Medline, PubMed, and CINAHL. Key words searched were "Desflurane", "Sevoflurane", "Recovery", and "Anesthesia." Key words were searched separately and combined to produce results. The time period searched was from 2014 to 2019. An initial broad search of “desflurane” on Medline produced 997 search results. While searching "sevoflurane" produced 4,658. Combining the terms "sevoflurane and "desflurane" on Medline showed 476 results. Adding the term "recovery" to the search yielded 123 results. Searching the four terms "desflurane", "sevoflurane", "recovery", and "anesthesia" resulted in 109 articles on Medline. Using the CINAHL database, the term "desflurane" was initially searched with 319 results. Adding the term "sevoflurane" with the other search terms produced 142 results. Combining the terms with "recovery" yielded 36 results. Lastly, adding the term "anesthesia" resulted in 34 research articles. The database PubMed was also used, yielding 913 results after searching "desflurane", and 436 results adding "sevoflurane to key terms. Combining previous search terms with "recovery" produced 114 results, and then adding "anesthesia" to the search terms reduced the articles to 109. Six articles met the inclusion criteria and were chosen for this review (Figure 1). 


\section{PRISMA 2009 Flow Diagram}

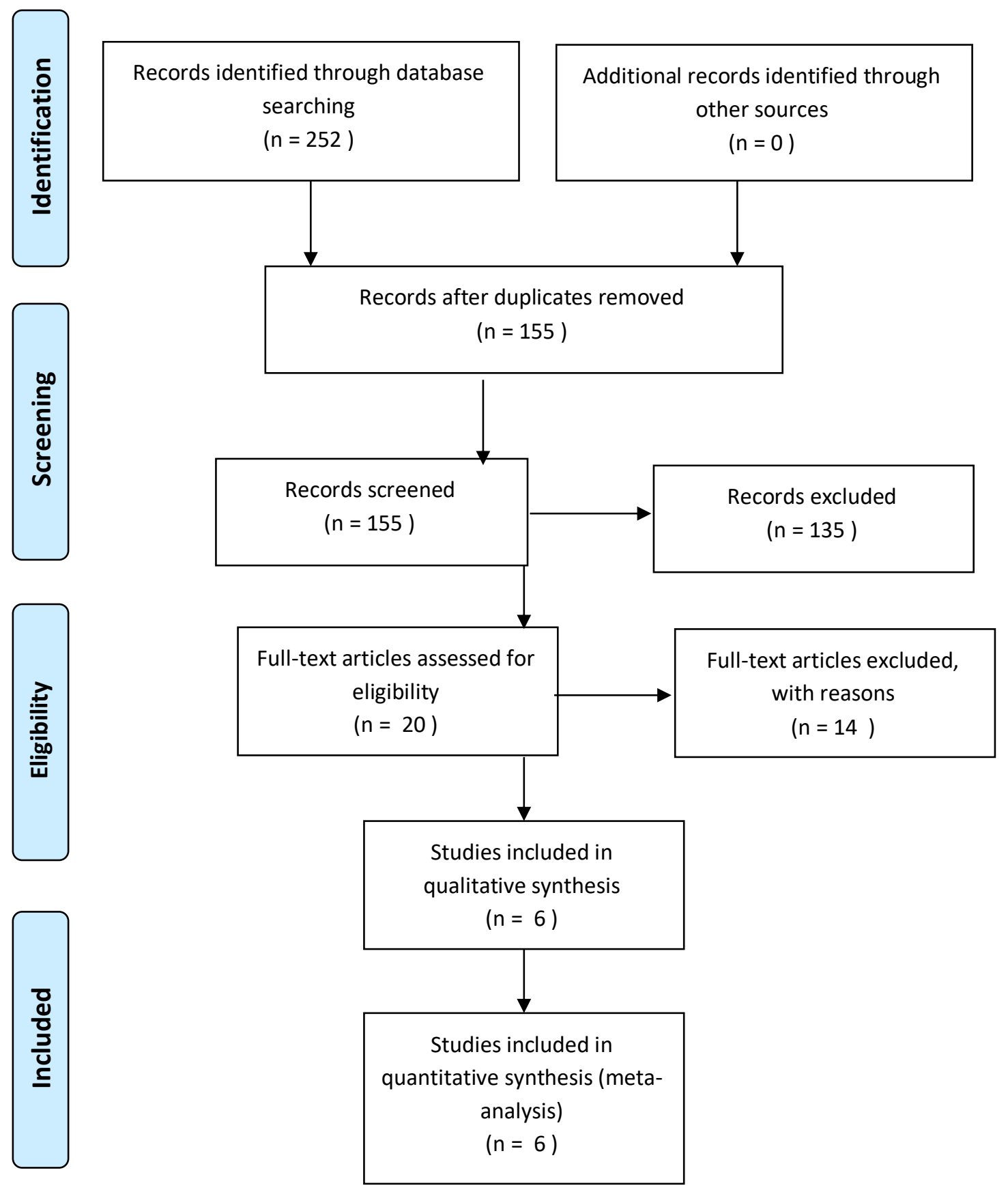

Figure 1. PRISMA Flow Diagram 
An RCT by Valasareddy et al. (2016) examined 60 adult patients undergoing general anesthesia for elective procedures consisting of general, ENT, and plastic surgeries. Thirty patients were randomly assigned by computer generation to two different groups receiving either desflurane or sevoflurane for maintenance of anesthesia. Exclusion criteria consisted of history of drug abuse, known drug allergy, morbid obesity, pregnant women, and a history of cardiopulmonary, hepatic, renal, neurological, or psychiatric illness. Vital signs were continuously recorded throughout the surgery as well as the MAC values of volatile agents. All patients were preoxygenated until receiving end tidal Oxygen of more than $95 \%$, given glycopyrrolate $0.2 \mathrm{mg} \mathrm{IV}$, fentanyl at $2 \mathrm{mcg} / \mathrm{kg} \mathrm{IV}$, an induction dose of IV propofol, and IV vecuronium, a paralytic to facilitate endotracheal intubation. Anesthesia was maintained with combinations of gases. Either desflurane, nitrous oxide, and oxygen were given simultaneously, or sevoflurane, nitrous oxide, and oxygen were administered. Paralysis was reversed at the end of the procedures with neostigmine and glycopyrrolate. The test drug and nitrous oxide were stopped after the last sutures were applied. Time taken for eye opening on verbal commands was noted on the operating room table. Patients were taken to PACU where they were continuously assessed using the Modified Aldrete Score (MAS). All 60 patients completed the study. Time taken for eye opening was 5.17 minutes for desflurane and 8.96 minutes for sevoflurane groups. The median score of 10 in MAS assessments was achieved by desflurane in 5 minutes and by sevoflurane in 15 minutes. Time to eye opening on verbal command was faster in the desflurane group $(\mathrm{p}=<0.001)$. At one minute the MAS was insignificant $(\mathrm{p}>0.05)$. A median score of 10 was attained at 5 minutes by desflurane and 15 minutes by sevoflurane which was statistically significant 
$(\mathrm{p}<0.001)$. So, this study concluded that desflurane had significantly faster emergence and recovery compared to sevoflurane. (Appendix G).

Sezen and Bombaci (2018) conducted an RCT comparing postoperative recovery after desflurane and sevoflurane anesthesia in adult patients aged 18-75 and ASA class I or II. Eighty patients were divided into two groups: Group I receiving desflurane and Group II receiving sevoflurane. All patients were scheduled for elective lower abdominal surgery with general anesthesia. Exclusion criteria consisted of anemia, cardiac, pulmonary, or neuromuscular diseases, obesity, smoking, and those having upper abdominal surgery or thoracic surgery. Patients were given $5-7 \mathrm{mg} / \mathrm{kg}$ of thiopental for induction of anesthesia along with $1 \mathrm{mcg} / \mathrm{kg}$ of Fentanyl and $0.6 \mathrm{mg} / \mathrm{kg}$ Rocuronium for muscle relaxation. In addition to either desflurane or sevoflurane, an oxygen/air mixture was used. There was no significant difference in the duration of surgery or anesthesia between the two groups. Volatiles were discontinued at the end of each procedure. Neuromuscular monitoring is standard when using paralytics (also referred to as muscle relaxants). Vecuronium, a paralytic was used, so this monitoring is required. The trainof-four ratio delivers four separate electrical stimuli to the patient and the provider monitors for twitches to aide in determining level of paralysis during anesthesia (Nagelhout \& Plaus, 2014). When the patient's train-of-four stimulation value exceeded $85 \%$ after paralysis reversal with atropine and neostigmine (meaning the patient's paralysis had been $85 \%$ recovered), the patients were extubated and oxygen was administered via facemask. Recovery time was calculated and recorded after $100 \%$ oxygen was administered to eye opening with verbal stimulation, time to extubation, and response to verbal commands. Aldrete scores were recorded in the PACU, along with 
pain score using the VAS scale, airway control value, and Spo2 levels. There was no statically significant difference in Aldrete Scores at 1 and 5 minutes, but the score was higher in the desflurane group at 10 minutes and afterwards. At 10 minutes, Group I had an Aldrete score of 9.42, while group II had a score of 8.87 which was found to be significant $(\mathrm{p}=0.002) . \mathrm{SpO} 2$ values were statistically higher in the desflurane group than the sevoflurane group at 5, 10, 20, 30, and 45 minutes. Sezen and Bombaci (2018) found that desflurane did provide a somewhat faster recovery and also stated that the lower levels of $\mathrm{SpO} 2$ in PACU of patients who received sevoflurane suggested that the respiratory depressant effect is greater and desflurane might be preferable in patients with a high risk of hypoxia (Appendix $\mathrm{H}$ ).

An RCT performed by Pakpirom, Kraithep, and Pattaravit (2015) explored the length of PACU stay in elderly patients after general anesthesia. The authors' purpose was to investigate the length of PACU stay and recovery profiles of elderly patients after receiving either desflurane or sevoflurane general anesthesia. Pakpirom et al. noted that the length of PACU stay was double the cost of a standard floor, or a basic hospital bed. Essentially, lessening the length of a patient's PACU stay would decrease service fees. The researchers were looking to compare the length of PACU time and recovery profiles of elderly patients comparing the two anesthetics, desflurane and sevoflurane. Their study took place at Songklanagarind Hospital from 2010 until 2012. Eighty patients who were over the age of 65 and classified as ASA I, II, or III were chosen to participate. Patients were excluded if it was thought they may need to remain intubated, received general anesthesia less than one week earlier, or had significant diagnoses such as cardiovascular or metabolic disease. Surgical type and duration were similar among the 
sample. Patients were divided into two groups; 38 in the desflurane group and 42 in the sevoflurane group. Patients did not receive any sedative drug preoperatively. In the operating room, patients were monitored with both standard and Bispectral index (BIS) index monitoring (to monitor level of consciousness during general anesthesia). Patients received IV fluids, IV at fentanyl $1-2 \mathrm{mcg} / \mathrm{kg}$ and $1-3.5 \mathrm{mg} / \mathrm{kg}$ of IV propofol for induction of anesthesia. Volatile anesthetic of choice in addition to air and oxygen combination were used to maintain anesthesia. Cisatricurium was the paralytic used for the entire sample. Paralysis was reversed at the end of each procedure with usual therapeutic doses IV of atropine and neostigmine. The anesthetic agents were discontinued once the skin incisions were closed. Nurses assessed and recorded the time from discontinuation of anesthetic to eye opening, response to commands, and extubation. Patients were transferred to PACU and further assessed by investigators every five minutes. Two patients in the sevoflurane group were excluded because of surgical time and the need to remain intubated. Blood loss, body temperature, amount of fentanyl administered, and surgical duration were comparable among the sample. The desflurane group recovered faster than the sevoflurane group. Time to open eyes was 7.5 and 9.6 minutes and time to respond to commands was 9.0 minutes and 11.2 minutes, respectively. However, there was no significant difference in time to extubation which was 12.4 minutes in the sevoflurane group and 10.4 minutes in the desflurane group. The length of PACU stay was also not significantly different. PACU stay in the sevoflurane group was 49.4 minutes, while the desflurane group remained in the PACU for 50.1 minutes. Pakpirum et al. (2015) found that while there was no significant difference in length of PACU stay, the desflurane group had faster early recovery measured by eye 
opening and following commands. The authors noted that due to the small sample size, the study might be underpowered (Appendix I).

McKay, Hall, and Hills' (2016) RCT described the differences between the volatiles desflurane and sevoflurane on airway reflex recovery in 81 paralyzed and intubated patients. Patients were classified as ASA physical class I or II and between the ages of 18 and 65. Patients had a BMI less than 35. Surgical length was between two and three hours. Patients were required to pass a swallow test prior to surgery because a swallow test after their surgical procedures would be a method of evaluation. Exclusion criteria consisted of: significant organ dysfunction, obstructive sleep apnea, delayed gastric emptying, reactive airway disease, and head and neck surgery. Patients received IV midazolam prior to entering the operating room. Patients were monitored with standard monitoring equipment including TOF neuromuscular monitoring. Patients received IV fentanyl at $1.5 \mathrm{mcg} / \mathrm{kg}, 1 \mathrm{mg} / \mathrm{kg}$ of IV lidocaine, and 1.0 to $3.5 \mathrm{mg} / \mathrm{kg}$ of IV propofol for induction of anesthesia. Neuromuscular monitoring was performed on the right or left ulnar nerve. Once mask ventilation was sufficient, patients were paralyzed with normal dosing of rocuronium for tracheal intubation. Sevoflurane or desflurane was used with a mixture of oxygen and air. Rocuronium and fentanyl were used throughout the procedure according to the anesthesia provider's assessments. Typical neostigmine and glycopyrrolate doses were used to reverse paralysis. Volatiles were decreased to 0.5 MAC end-tidal pressure during wound closure. Anesthetic was discontinued when TOF reached equal or greater than 0.7 . The anesthesia providers communicated with patients by stating commands "open your eyes" and "squeeze my hand", and then extubated when appropriate. Two minutes after the patients' response to a command they were asked to 
swallow $20 \mathrm{~mL}$ of water. Swallowing effort was evaluated and met when a patient drank the entire $20 \mathrm{~mL}$ and did not drool, cough, gag, or pool water in the hypopharynx. This was repeated at $6,14,22,30$, and 60 minutes. Three different time intervals were compared: time from discontinuation of anesthetic until first response to command; time from first response until ability to swallow; and time from discontinuation of anesthetic gas to ability to swallow. If a researcher felt that a patient was too somnolent to swallow, the patient was recorded as failing the swallow study. Anesthesia with desflurane was significantly associated with the ability to swallow at 2 minutes. Failure to pass at 2 minutes was associated with nonadherence to neuromuscular protocol. Authors observed a significantly higher chance of passing at 2 minutes after first response to command in patients receiving desflurane compared with those receiving sevoflurane $(p=0.006)$ According to this study, desflurane patients had a faster and more consistent recovery of protective airway reflexes compared to the sevoflurane patients (Appendix J).

An RCT performed by Gokcek et al. (2016) examined early postoperative recovery after intracranial surgical procedures in desflurane verses sevofluranemaintained anesthesia. Fifty patients aged 18-70 scheduled to undergo craniotomy for intracranial lesions and ASA status I or II participated in this study. Patients were separated into two groups, a desflurane receiving group and sevoflurane receiving group, with 25 patients in each group. This study obtained approval from the IRB and ethics committees and was performed at the Istanbul University in 2011. Exclusion criteria consisted of significant organ dysfunction, obesity, or known hypersensitivity to any anesthetic agent. Preoperatively, patients did not receive IV sedation. Patients received IV fluids and standard monitoring was initiated and maintained while in the operating 
room. The adductor pollicis and ulnar nerve were used for neuromuscular monitoring and body temperature was monitored with bladder catheters. Anesthesia was induced by administering appropriate doses of IV medication such as midazolam, fentanyl, and propofol. Paralysis was achieved and maintained with IV vecuronium. In addition to either sevoflurane or desflurane a mixture of air and oxygen were delivered to patients. IV Remifentanil was administered to the entire sample as $0.05-0.2 \mathrm{mcg} / \mathrm{kg} / \mathrm{minute}$ during surgery. Neuromuscular blockade was reversed with typical doses of IV neostigmine and atropine. Times used to evaluate recovery were: emergence time, extubation time, hand squeezing time, and time from eye opening to verbal command. Spatial, temporal, and personal orientation were also evaluated in addition to the time required to achieve a modified Aldrete score of 9-10. Time to respond to painful stimulus in the desflurane group was 4.8 minutes verses 7.7 minutes in the sevoflurane group. Extubation time in the desflurane group was 7.1 minutes verses 10.1 minutes in the sevoflurane group. Time to modified Aldrete score of 9-10 was 15.8 minutes in the desflurane group, while it took the sevoflurane group 23.3 minutes to achieve. The authors noted that desflurane has some advantages in neurosurgical patients due to the faster ability to obtain a neurological exam. Goceck et al. (2016) also discussed that the short-acting Remifentanil may have provided earlier recovery properties as well. The times to responses to painful stimuli, emergence, hand-squeezing, extubation, orientation, and Aldrete score of 9-10 were significantly lower with desflurane than they were with sevoflurane $(p<0.001)$. In conclusion, the researchers stated that desflurane resulted in earlier recovery and shorter extubation times than sevoflurane (Appendix K). 
Gangakhedkar and Monteiro (2019) performed an RCT examining the anesthetic agents desflurane and sevoflurane and the differences in their early recovery profiles. Sixty patients ages 20-60 who were ASA class I or II were split into two groups of thirty. All patients underwent a laparoscopic cholecystectomy for gallbladder disease. The sample was administered typical doses of IV fentanyl and glycopyrrolate. Anesthesia was induced with IV propofol, while paralysis was initiated and maintained with IV atracurium. Patients were intubated with oral endotracheal tubes and anesthesia was maintained with either desflurane or sevoflurane in combination with air and oxygen as carrier gasses. IV agents such as fentanyl, pantoprazole, ondansetron, and paracetamol were administered to all patients. Anesthetic depth was determined using BIS. Volatile agents were discontinued after the last skin suture was placed. Neuromuscular blockade was reversed with appropriate doses of IV glycopyrrolate and neostigmine. Investigators recorded the time to extubation, eye opening, verbal response and the time at which patients received a modified Aldrete score of at least 9. After receiving a score of 9 or higher, patients were taken to the PACU. The desflurane group was a higher mean modified Aldrete score at time of extubation than the sevoflurane group, 7.07 and 6.0 respectively. The Aldrete scores were higher in the desflurane group at 1, 3, and 5 minutes after extubation. This RCT demonstrated that the early recovery profile of desflurane was indeed better than that of sevoflurane. Gangakhedkar et al, (2019) noted that the number of patients who suffered from respiratory complications such as excessive secretions, coughing, and bronchospasm was higher in the desflurane group, but was not statistically significant. Limitations consisted of the sample not including 
geriatric or obese patients that could have possibly benefited from a faster recovery from anesthesia (Appendix L).

\section{Critical Appraisal}

The six randomized control trials discussed have been critically appraised using the Critical Appraisal Skills Programme (CASP).

In the study by Valasareddy et al. (2018) 60 patients were divided into 2 groups of 30 to examine the effects of sevoflurane versus desflurane and the differences in emergence and recovery. All 60 patients completed the study. All CASP questions were answered "yes" except for all patients, health workers, and study personnel being "blind" to treatment. The study did not discuss whether or not those involved were blinded. Both groups were similar at the start, consisting of ASA class I or II and all participants underwent laparoscopic cholecystectomy. Groups were treated equally and there were no adverse events. Time to spontaneous eye opening on verbal command was significantly faster in the desflurane group (8.96 minutes for sevoflurane and 5.17 minutes for the desflurane group). It was significant with a $95 \%$ confidence interval. Findings in this study were appropriate for this systematic review (Appendix M).

Sezen and Bombaci (2018) compared the early postoperative recovery of 80 patients undergoing lower abdominal surgery. The participants were divided into two groups and received either desflurane or sevoflurane inhaled anesthesia. The study did not clearly state if all participants completed the study or if everyone was blinded.

Groups were similar in that they were ASA class I or II, no premedication was given, and all participants were adults 20-60 years old. In examining the Aldrete Scores, the desflurane group had higher scores at 10 minutes and afterwards. At ten minutes $\mathrm{p}=$ 
0.0145 , which the authors stated was significant. The precision or power level is not stated. Findings in this study were appropriate for this systematic review. No harm to participants was noted (Appendix N).

Pakpirom et al. (2016) compared the length of PACU stay in 80 elderly patients after general anesthesia receiving either desflurane or sevoflurane. Two patients did not finish the trial because of their need to remain intubated postoperatively. While the study was double-blinded, the anesthesia providers were not blinded because of their need to adjust the gasses to maintain an adequate level of anesthesia. Both groups were similar in that they were all 65 years of age or older and they were all ASA II or III status and were treated similarly throughout the study. Patients in the desflurane group recovered significantly faster than the patients in the sevoflurane group as indicated by the time to open eyes ( 7.5 verses 9.6 minutes) and time to follow commands ( 9.0 and 11.2 minutes). Time to eye opening had a $\mathrm{P}$ value of 0.04 and time to follow commands had a $\mathrm{P}$ value of 0.05. The power of the study was not discussed. Findings were appropriate for this paper and no harms or costs were mentioned (Appendix O).

McKay et al. (2016) studied the effects of sevoflurane versus desflurane and neuromuscular management on the speed of airway reflex recovery. Eighty-one patients were randomly assigned to two groups. While the technician was blinded to the anesthetic gas, the anesthesia providers received an envelope with an assignment of the anesthetic gas to be used. Groups were similar at the start of the trial and treated equally throughout. Time from anesthetic discontinuation to first appropriate response to command was shorter in the desflurane group $(p=0.0001)$. Time to the ability to swallow was also shorter in the desflurane group $(\mathrm{p}=0.0007)$. Confidence Intervals 
noted were $95 \%$. This study, due to its comparison of sevoflurane versus desflurane, is relevant for this systematic review. Harm to patients and cost analysis were not discussed in this review (Appendix P).

Gökçek et al. (2016) compared the effects of sevoflurane and desflurane of 50 patients undergoing craniotomy for intracranial lesions. Early postoperative recovery was assessed by times to painful stimuli, emergence, hand-squeezing, extubation, orientation and Aldrete Score. Patients were comparable at the start of the trial and were treated equally throughout. The times to respond to a painful stimulus, interval from eye opening to command, and times to extubation, handgrip, orientation and achievement of an Aldrete score of 9-10 were found to be significantly shorter in the desflurane group $(\mathrm{p}<0.001)$. Power of the study is not discussed. This study is relevant to this paper as it compares desflurane to sevoflurane and the clinically important outcomes. The authors did not discuss harm and/or costs of their study (Appendix Q).

Gangakhedkar \& Monteiro (2019) performed a prospective randomized doubleblinded study, which compared the early recovery profiles of desflurane and sevoflurane in patients undergoing laparoscopic cholecystectomy. Patients were randomized into two groups using computer-generated tables. This article did not state whether or not all participants finished the study. While the study was double-blinded, it does not discuss the anesthesia providers who most likely could not have been blinded. Both groups were comparable at the beginning of the trial including age, BMI, and ASA classification. They were also treated equally throughout the study. The mean modified Aldrete score was significantly higher at extubation in the desflurane group (7.07) compared to the sevoflurane group (6.), $\mathrm{p}<0.001$. The modified Aldrete scores remained significantly 
higher in the desflurane group at 1,3 , and 5 minutes postextubation $(8.2$ vs $6.5, \mathrm{p}<0.001$; 8.8 vs $7.4, \mathrm{p}<0.001 ; 9.0$ vs $8.2, \mathrm{p}=0.036$ ). This study used the modified Aldrete score which considers moving extremities on command, breathing effort, and consciousness. The power of the study was not discussed, nor were any costs or harm. The results of this study can be applied to this systematic review (Appendix R).

\section{Cross Analysis}

The randomized control trials of this systematic review were analyzed across studies (Appendix S). The cross analysis compared the recovery time of patients after undergoing general anesthesia maintained by sevoflurane or desflurane.

The randomized control trials included in this systematic review examined different elective (non-emergent surgeries), but the anesthesia provided for each surgery was comparable among the studies. Patients all received general anesthesia with either desflurane or sevoflurane and required endotracheal intubation with muscle relaxation. Valasareddy et al., (2018) investigated patients undergoing surgical procedures such as plastic, ears, nose, and throat (ENT), and general surgeries. Sezen \& Bombaci (2018) examined patients undergoing lower abdominal surgery, while Pakpirom et. al., (2015) sampled elderly patients having abdominal, laparoscopic, ENT, and kidney operations. McKay et. al., (2016) researched patients undergoing surgeries 2-3 hours in length requiring general anesthesia with endotracheal tube and paralysis and did not report which types of procedures were performed. Gokcek et al., (2016) investigated patients undergoing intracranial surgeries. Gangakhedkar \& Monteiro (2019) examined patients having laparoscopic cholecystectomies requiring general anesthesia. Even though the 
surgeries performed were different among each individual study, the results supported desflurane providing a faster recovery from anesthesia than sevoflurane.

The six RCTs defined their recovery scale differently and used more than one type of measurement in their studies. The MAS and time to eye opening were used in four of the studies. One study used time to follow commands, while another used length of PACU stay. The time to first ability to swallow was used in an individual study because that RCT focused on airway protection. Finally, one study used time to pull from painful stimulus as a measurement of recovery. While recovery scales differed among studies, results were similar across studies, supporting desflurane faster recovery profile.

Valasareddy et. al., (2018) compared sevoflurane versus desflurane and the patient's time to eye opening on verbal command and how long it took to get to a MAS of 10. Patients in the desflurane group had a MAS of 10 at 5 minutes, while it took the sevoflurane group 15 minutes. Eye opening on verbal command took 5.17 minutes in the desflurane group and 8.96 minutes in the sevoflurane group. The authors did mention that there was in increase in heart rate with the desflurane group, but no increase in blood pressure. There were also no episodes of desaturation, coughing, bronchospasm, or laryngospasm on induction or extubation, and no postoperative nausea and vomiting (PONV) among those studied. Sezen \& Bombaci (2018) also used time to eye opening on verbal command and a MAS score. Eye opening on verbal command took 5.80 minutes for the desflurane group and 6.3 minutes for the sevoflurane group. A MAS score of 9 was accomplished at 10 minutes for the desflurane group and at 15 minutes for the sevoflurane group. The authors also discussed that postoperative $\mathrm{SpO} 2$ (oxygen 
saturation in arterial blood) was significantly higher in the desflurane group after 5 minutes in PACU (98.48 versus 97.38), which they found to be significant ( $p=0.0049$ ). Pakpirom et al's. RCT examined elderly patients and found participants demonstrated faster early recovery measured by time to eye opening ( 7.5 minutes for desflurane and 9.6 minutes for sevoflurane) and following commands (9.0 minutes for desflurane and 11.2 minutes for sevoflurane). However, their results showed similar lengths of PACU stay with desflurane patients' time being slightly longer (50.1 minutes) than sevoflurane patients (49.4 minutes). McKay et al., (2016) examined the speed of airway reflex recovery and measured the time at which patients could swallow after receiving either desflurane or sevoflurane-maintained anesthesia. Time from discontinuation of anesthesia to first appropriate response took 4.83 minutes for desflurane patients and 9 minutes for the sevoflurane group. Time from anesthetic discontinuation to first ability to swallow took 9 minutes for the desflurane group and 16 minutes for those who received sevoflurane. Time from first response to first ability to swallow was also faster in the desflurane group ( 2 minutes) than the sevoflurane group (6 minutes). The researchers concluded that desflurane provided faster and more consistent recovery of protective airway reflexes. Gokcek et al., (2016) compared the postoperative effects of desflurane and sevoflurane after intracranial surgery and used time to react painful stimuli (4.8 minutes for desflurane group and 7.7 minutes for sevoflurane group) and achieve a MAS of 9-10 (15.8 minutes for desflurane and 23.3 minutes for sevoflurane) to define recovery. The authors stated that desflurane has some potential advantages resulting from its uptake and recovery characteristics in the neurosurgical patient. Practitioners could be able to recognize and treat potential postoperative complications earlier with 
desflurane. Finally, Gangakhedkar \& Monteiro’s 2019 RCT examined the recovery profiles of patients undergoing laparoscopic cholecystectomies and used time to eye opening (6.3 minutes for desflurane and 10.1 minutes for sevoflurane) and a MAS of 9 (11.1 minutes for desflurane and 17.1 for sevoflurane) to define recovery from anesthesia. The authors noted that complications such as secretions, coughing, and bronchospasm occurred more frequently in the desflurane group, but stated that it was not statistically significant. Gangakhedkar and Monteiro (2019) concluded that enhanced early recovery can translate into faster discharge readiness from the PACU. These results support desflurane providing an earlier postoperative recovery than that of sevoflurane. 


\section{Summary and Conclusions}

While general anesthesia is extremely safe today, there are still complications that exist. General anesthesia decreases a person's functional residual capacity (FRC), meaning that the amount of air in the lungs after exhalation is less while under anesthesia, even if the patient is still spontaneously breathing (Nagelhout \& Plaus, 2014). While being mechanically ventilated, the FRC decreases even more because the diaphragm is no longer contributing to ventilation (Nagelhout \& Plaus, 2014). General anesthesia can cause atelectasis, pneumonia, and respiratory failure postoperatively (Nagelhout \& Plaus, 2014). This can lead to longer hospital stays, higher costs, and far worse outcomes for patients. According to Nagelhout \& Plaus (2014), the most frequent cause of airway obstruction in PACU is due to loss of pharyngeal muscle tone due to a patient being too sedated after surgery. If medical professionals are unable to relieve the obstruction, a patient might need to be reintubated. Patients in the PACU can also suffer from hypoxia as a result of airway obstruction, hypoventilation, atelectasis, aspiration, bronchospasm or laryngospasm (Nagelhout \& Plaus, 2014). Airway reflexes that are not fully recovered after anesthesia can cause patients to aspirate on secretions, blood, or vomitus. It is extremely important for anesthesia providers and PACU nurses to ensure that patients will adequately breathe and protect their airways.

Volatile anesthetics are ideal for recovery from anesthesia because their low blood-gas solubility allows for a rapid emergence. Volatiles affect our respiratory system by decreasing our tidal volume (the amount of air we are able to breathe in and out) and by depressing our ability to respond to high levels of carbon dioxide (CO2) (Nagelhout \& Plaus, 2014). Ventilatory response to hypoxia (low oxygen) is also depressed with inhalation agents. This, in addition to a combination of intravenous medications 
anesthesia providers administer to patients can result in respiratory issues postoperatively. While most patients recover safely, risks always exist. The purpose of this systematic review was to compare the recovery profiles of two frequently used volatile gasses: desflurane and sevoflurane and to examine whether or not one provided faster postoperative recovery.

A literature review was conducted utilizing inclusion and exclusion criteria generated by the author. The databases searched were Cochrane, Medline, PubMed, and Google Scholar. The PRISMA flowchart was used to guide the search strategy. Six randomized control trials were chosen for inclusion. Data collection tables were created for all six articles. Information gathered from each research article included purpose, setting, sample, design method, surgical procedure, recovery scale used, results, and limitations. After data collection, a critical appraisal of each article was performed. The CASP checklist was used to guide this, examining how comparable both research groups were, the study being blinded, relevance to this review, strength or the research, and any cost or harm. Analysis across studies focused on the type of surgical procedure, the recovery scale used, and time to recovery for sevoflurane and desflurane.

All six randomized control trials in this systematic review reported faster recovery with desflurane. Four out of the six studies used the modified Aldrete scoring system in PACU to evaluate readiness for discharge. They all showed higher scores faster with desflurane. McKay et al. (2016) also showed that patients who were anesthetized with desflurane regained swallowing ability faster than those who received sevoflurane in addition to responding to command earlier, showing that protective reflexes were intact faster. In addition to the MAS, Gökçek et al. (2016) focused on eye opening and 
extubation time to be able to perform a neurological exam after intracranial surgery. Authors noted that a benefit of desflurane is the faster ability to ensure that a patient is neurologically intact after intracranial surgery.

After thorough evaluation of the literature, limitations to this systematic review were identified. Each study focused on a different type of surgery or looked at the postoperative recovery profile after multiple different types of surgeries. One could make the argument that the review should focus on one type of surgery because there are different expectations for recovery. But it could also be argued that not enough different types of surgical procedures were examined, and for better results desflurane would have to show faster recovery in all types of procedures. For example, these were all elective or non-emergent surgeries. Another limitation of this systematic review is that while the studies did state the time the volatile gas anesthetic was discontinued, how fast or slowly the gas percentage was decreased was not discussed and speed could make wake up time speedier or prolonged. An earlier and greater decrease in the gas anesthetic could definitely lead to a faster emergence than if the anesthetic was left fully on and discontinued when the last stitch was applied. Five of the six studies included ASA I and II's in their research, while one study included ASA III and focused on the elderly patients' recovery from anesthesia. While a majority of the studies used MAS and/or eye opening to define recovery from anesthesia, there were differences in the description of recovery and numerous scales to measure recovery among the six studies. Although these limitations exist, the purpose of this systematic review was achieved. 
Despite limitations, this systematic review provides evidence that desflurane use for general anesthesia results in faster recovery time for surgical patients. Next, recommendations and implications for advanced practice nursing will be discussed. 


\section{Recommendations and Implications for Advanced Nursing Practice}

Most anesthesia providers would state that desflurane has a quicker offset than sevoflurane, resulting in a much faster wakeup for their patients. The purpose of this systematic review was to examine whether or not desflurane results in a faster and safer recovery after general anesthesia than sevoflurane. This review provides evidence that desflurane use over sevoflurane provides a significantly faster recovery from general anesthesia. Applying this to practice, especially in the elderly population, patients at risk for respiratory depression, and patients with neuromuscular conditions affecting their respiratory status, should be implemented. There are many surgical facilities that do not offer desflurane because it is more expensive than other volatile gasses. Due to its advantages in the postoperative recovery period, facilities should make desflurane available for anesthesia providers.

Like all medical professionals, Certified Registered Nurse Anesthetists must use evidence-based research to guide their practice. Systematic reviews have been utilized by medical doctors, nurse practitioners, and CRNAs. This systematic review could aid in future research regarding improved and speedier postoperative recovery for our patients.

This systematic review researched the most current literature discussing the recovery profiles of desflurane and sevoflurane. This review provides evidence that the use of desflurane leads to earlier eye opening, a higher earlier MAS, improved airway reflexes faster, ability to perform a neurological exam faster, and earlier response to painful stimuli. Applying this research to practice is the next step. Once more research can be conducted, education can then take place, and finally use of desflurane more consistently can be applied in the clinical area. There would, however, be times when desflurane is not the ideal anesthetic. For example, if a patient with coronary artery 
disease is tachycardic, the anesthesia provider may want to switch the anesthetic to one that does not cause an increase in heart rate.

The use of desflurane in more hospitals and surgery centers has been proposed, but further research is needed on this topic. The RCTs in this systematic review vary in types of surgical procedures, yet also lack a number of surgeries that would give us a better look at the recovery profile of desflurane in all cases. Identifying specific cases where desflurane is the ideal candidate for choice of anesthetic is key. For example, desflurane use can aid in faster detection and treatment of postoperative complications after neurosurgical procedures.

Future recommendations include further study on desflurane in both elective and emergency surgeries. Published studies have supported the hypothesis that desflurane shows faster recovery after general anesthesia than that of sevoflurane. While more research on this topic is required, the benefits of facilities providing desflurane as an option for anesthesia has been supported. 


\section{References}

Barash, P. G., Cullen, B. F., Stoelting, R. K., Cahalan, M. K., Stock, M. C., \& Ortega, R.

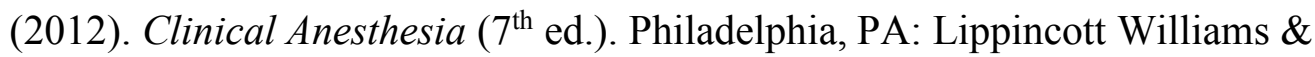
Wilkins.

Butterworth, J. F., Mackey, D. C., \& Wasnick, J. D. (2013). Morgan \& Mikhail's Clinical Anesthesiology (5 $5^{\text {th }}$ ed.). United States: McGraw-Hill Companies.

Eger, E. I. (2004, October 15). Characteristics of anesthetic agents for induction and maintenance of general anesthesia. American Society of Health-System Pharmacists, Inc., 61(4), 53-59. Retrieved from https://www.ebsco.com/

Esper, T., Wehner, M., Meinecke, C.-D., \& Rueffert, H. (2015). Blood/Gas partition coefficients for isoflurane, sevoflurane, and desflurane in a clinically relevant patient population. Anesthesia And Analgesia, 120(1), 45-50. https://doiorg.ric.idm.oclc.org/10.1213/ANE.0000000000000516

Gangakhedkar, G., \& Monteiro, J. (2019). A prospective randomized double-blind study to compare the early recovery profiles of desflurane and sevoflurane in patients undergoing laparoscopic cholecystectomy. Journal of Anaesthesiology Clinical Pharmacology, 35(1), 53-57. https://doiorg.ric.idm.oclc.org/10.4103/joacp.JOACP_375_17

Gökçek, E., Kaydu, A., Akdemir, M. S., Akil, F., \& Akıncı, I. O. (2016). Early postoperative recovery after intracranial surgical procedures. Comparison of the effects of sevoflurane and desflurane. Acta Cirurgica Brasileira, 31(9), 638-644. https://doi-org.ric.idm.oclc.org/10.1590/S0102-865020160090000010 
Horwitz, M., \& Jakobsson, J.G. (2016). Desflurane and sevoflurane use during low-and minimal-flow anesthesia at fixed vaporizer settings. Minerva Anesesiologica, 82(2), 180-185. Retrieved from http://www.siaarti.it/SiteAssets/Lists/minervaanestesiologica/AllItems/Minerva\% 20Anestesiologica\%20-\%20February\%202016.pdf\#page=41

Kim, J. M., Lee, J. H., Lee, H. J., \& Koo, B. (2013, March 19). Comparison of emergence time in children undergoing minor surgery according to anesthetic: Desflurane and Sevoflurane. Yonsei Medical Journal, 54. https://doi.org/10.3349/ymj.2013.54.3.732

Mason, K. P., Michna, E., Zurakowski, D., Burrows, P. E., Pirich, M. A., Carrier, M., Fontaine, P. J., \& Sethna, N. F. (2006). Value of bispectral index monitor in differentiating between moderate and deep Ramsay Sedation Scores in children. Pediatric Anesthesia, 16(12), 1226-1231. https://doi-org.ric.idm.oclc.org/1$.111 / \mathrm{j} .1460-9592.2006 .01975 . \mathrm{x}$

McKay, R. E., Hall, K. T., \& Hills, N. (2016). The effect of anesthetic choice (sevoflurane versus desflurane) and neuromuscular management on speed of airway reflex recovery. Anesthesia And Analgesia, 122(2), 393-401. https://doiorg.ric.idm.oclc.org/10.1213/ANE.0000000000001022

Mikuni, I., Harada, S., Yakushiji, R., \& Iwasaki, H. (2016). Effects of changing from sevoflurane to desflurane on the recovery profile after sevoflurane induction: A randomized controlled study. Canadian Journal Of Anaesthesia = Journal Canadien D'anesthesie, 63(3), 290-297. https://doiorg.ric.idm.oclc.org/10.1007/s12630-015-0514-9 
Moher, D., Liberati, A., Tetzlaff, J., Altman, D.G., \& the PRISMA Group. (2009). Preferred reporting items for systematic reviews and meta-analyses: The PRISMA statement. Annals of Internal Medicine, 151(4), 264-270.

Misal, U. S., Joshi, S. A., \& Shaikh, M. M. (2016, May-Aug). Delayed recovery from anesthesia: A postgraduate educational review. US National Library of Medicine, 10. https://doi.org/10.4103/0259-1162.165506

Nagelhout, J. J., \& Plaus, K. L. (2014). Nurse Anesthesia (5th ed.). St. Louis, Missouri: Elsevier Saunders.

Pakpirom, J., Kraithep, J., \& Pattaravit, N. (2016). Length of postanesthetic care unit stay in elderly patients after general anesthesia: A randomized controlled trial comparing desflurane and sevoflurane. Journal Of Clinical Anesthesia, 32, 294 299. https://doi-org.ric.idm.oclc.org/10.1016/j.jclinane.2015.08.016

Ringblom, J., Wahlin, I., \& Proczkowska, M. (2018). A psychometric evaluation of the Pediatric Anesthesia Emergence Delirium scale. Pediatric Anesthesia, 28(4), 332337. https://doi-org.ric.idm.oclc.org/10.1111/pan.13348

Rukirojindakul, P., Geater, A. F., McNeil, E. B., Vasinanukorn, P., Prathep, S., Asim, W., \& Naklongdee, J. (2012, October). Risk factors for reintubation in the postanaesthetic care unit: a case-control study. British Journal of Anaesthesia, 109. https://doi.org/10.1093/bja/aes226

Sezen, Ö., \& Bombacı, E. (2018). Comparison of early postoperative recovery after desflurane or sevoflurane anesthesia. Southern Clinics of Istanbul Eurasia, 29(3), 161-167. https://doi-org.ric.idm.oclc.org/10.14744/scie.2018.44265 
Valasareddy, S. K., Titu, O. G., Anil, P. R., Segaran, S. K., George, S. K., \& Ranjan, R. V. (2018). Recovery profile using modified Aldrete score in post anaesthesia care unit after sevoflurane or desflurane anaesthesia: A prospective 44andomized study. Journal of Clinical \& Diagnostic Research, 12(9), 1-4. https://doiorg.ric.idm.oclc.org/10.7860/JCDR/2018/35345.11963

Wu, X., Shan, C., Peng, B., Shi, X., Zhang, F., \& Cao, J. (2019, June). Comparison of desflurane and sevoflurane on postoperative recovery quality after tonsillectomy and adenoidectomy in children. Experimental \& Therapeutic Medicine, 17. Retrieved from https://www.ebsco.com/products/research-databases/academicsearch-complete 


\section{Appendix A}

\begin{tabular}{|c|c|c|c|c|c|c|c|}
\hline \multirow{2}{*}{ TABLE 50-4 } & \multicolumn{7}{|c|}{ Aldrete Postanesthesia Scoring System } \\
\hline & & & Admit & $15 \mathrm{~min}$ & $30 \mathrm{~min}$ & $45 \mathrm{~min}$ & $60 \mathrm{~min}$ \\
\hline \multirow{3}{*}{ Activity } & Able to move voluntarily on command & Four extremities & 2 & 2 & 2 & 2 & 2 \\
\hline & & Two extremities & 1 & 1 & 1 & 1 & 1 \\
\hline & & No extremities & 0 & 0 & 0 & 0 & 0 \\
\hline \multirow[t]{3}{*}{ Respiration } & Able to breathe deeply, cough freely & & 2 & 2 & 2 & 2 & 2 \\
\hline & Dyspnea or limited breathing & & 1 & 1 & 1 & 1 & 1 \\
\hline & Apnea & & 0 & 0 & 0 & 0 & 0 \\
\hline \multirow[t]{3}{*}{ Circulation } & $\mathrm{BP} \pm 20 \mathrm{mmHg}$ of preanesthesia level & & 2 & 2 & 2 & 2 & 2 \\
\hline & $\begin{array}{l}\mathrm{BP} \pm 20-50 \mathrm{mmHg} \text { of preanesthesia } \\
\text { level }\end{array}$ & & 1 & 1 & 1 & 1 & 1 \\
\hline & $\mathrm{BP} \pm 50 \mathrm{mmHg}$ of preanesthesia level & & 0 & 0 & 0 & 0 & 0 \\
\hline \multirow[t]{3}{*}{ Consciousness } & Fully awake & & 2 & 2 & 2 & 2 & 2 \\
\hline & Arousable on calling & & 1 & 1 & 1 & 1 & 1 \\
\hline & Not responding & & 0 & 0 & 0 & 0 & 0 \\
\hline \multirow[t]{3}{*}{$\mathrm{O}_{2}$ Saturation } & $\begin{array}{l}\text { Able to maintain } \mathrm{O}_{2} \text { saturation greater } \\
\text { than } 90 \% \text { on room air }\end{array}$ & & 2 & 2 & 2 & 2 & 2 \\
\hline & $\begin{array}{l}\text { Needs } \mathrm{O}_{2} \text { inhalation to maintain } \mathrm{O}_{2} \\
\text { saturation greater than } 90 \%\end{array}$ & & 1 & 1 & 1 & 1 & 1 \\
\hline & $\begin{array}{l}\mathrm{O}_{2} \text { saturation less than } 90 \% \text { even with } \\
\mathrm{O}_{2} \text { supplementation }\end{array}$ & & 0 & 0 & 0 & 0 & 0 \\
\hline
\end{tabular}

(Nagelhout, 2014) 


\section{Appendix B}

\begin{tabular}{lc} 
Ramsay Sedation Score \\
\hline Indicate sedation level \\
\hline 1 & Anxious, agitated, restless \\
2 sedation & Oriented, tranquil \\
3 sedation & Response to commands \\
4 sedation & Brisk response to light glabellar tap \\
5 sedation & Sluggish response to light glabellar tap \\
6 deep sedation & No response \\
\hline
\end{tabular}

(Mason et al, 2006) 


\begin{tabular}{|c|c|c|c|c|c|}
\hline \multicolumn{6}{|c|}{ Appendix C } \\
\hline & \multicolumn{5}{|c|}{ Behavior frequency } \\
\hline & None & Some & Modest & Much & Extreme \\
\hline $\begin{array}{l}\text { 1. Child makes eye } \\
\text { contact with caregiver. }\end{array}$ & 4 & 3 & 2 & 1 & 0 \\
\hline $\begin{array}{l}\text { 2. Child's action is } \\
\text { purposeful. }\end{array}$ & 4 & 3 & 2 & 1 & 0 \\
\hline $\begin{array}{l}\text { 3. Child is aware of his/ } \\
\text { her surroundings }\end{array}$ & 4 & 3 & 2 & 1 & 0 \\
\hline 4. Child is restless & 0 & 1 & 2 & 3 & 4 \\
\hline 5. Child is inconsolable & 0 & 1 & 2 & 3 & 4 \\
\hline
\end{tabular}

(Pediatric Anesthesia Emergence Delirium scale, Ringblom et al., 2018) 


\section{Appendix D}

\section{PRISMA 2009 Checklist}

$\pm$

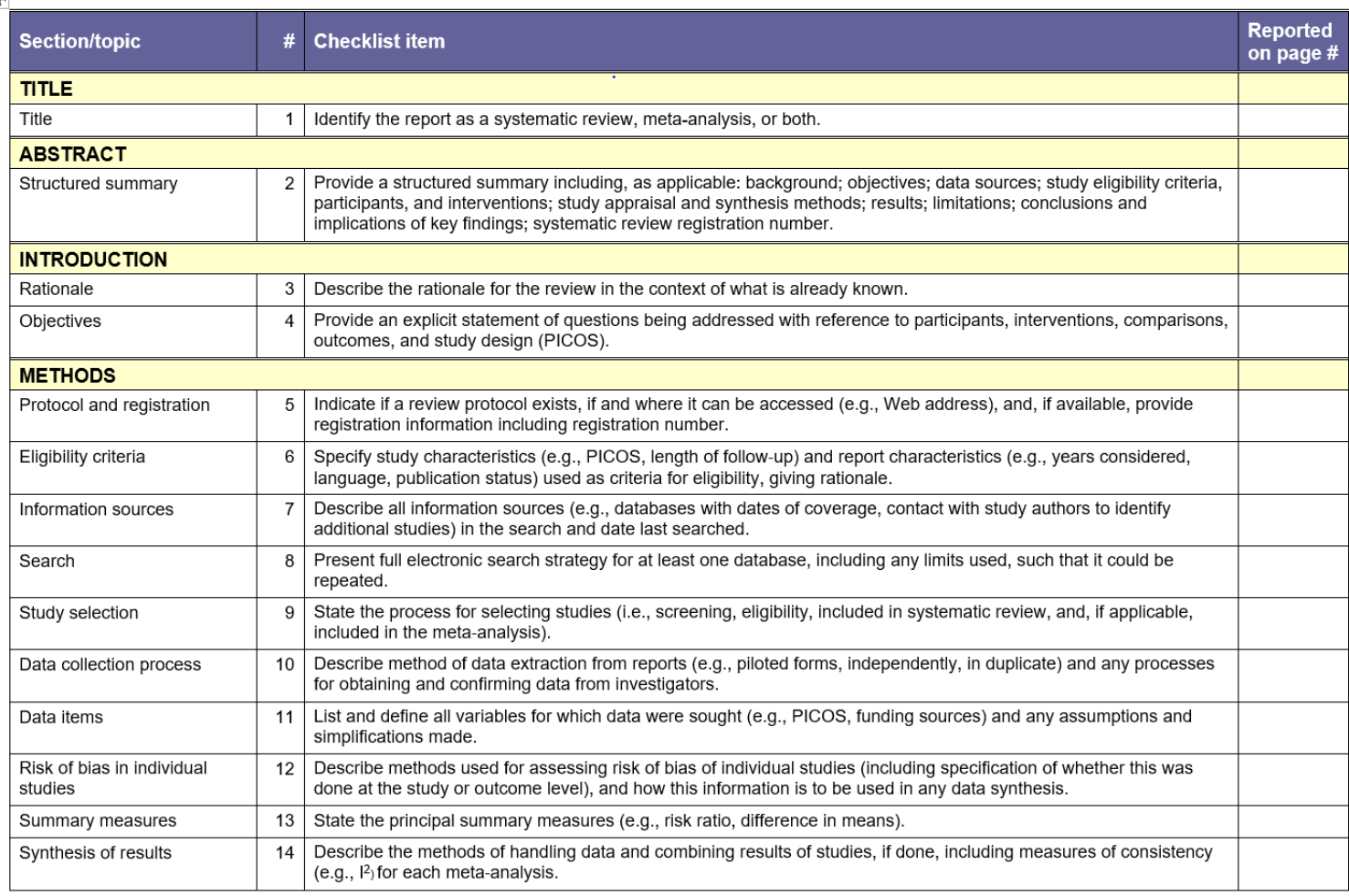

(Moher et al., 2009) 
Appendix E

PRISMA 2009 Flow Diagram

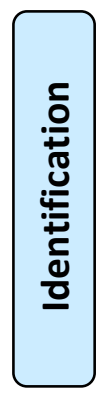

\begin{tabular}{|} 
Records identified through database \\
searching \\
$(\mathrm{n}=)$
\end{tabular}

Additional records identified through other sources

$$
(n=)
$$

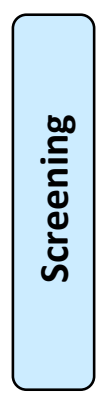

Records after duplicates removed

$$
(n=)
$$
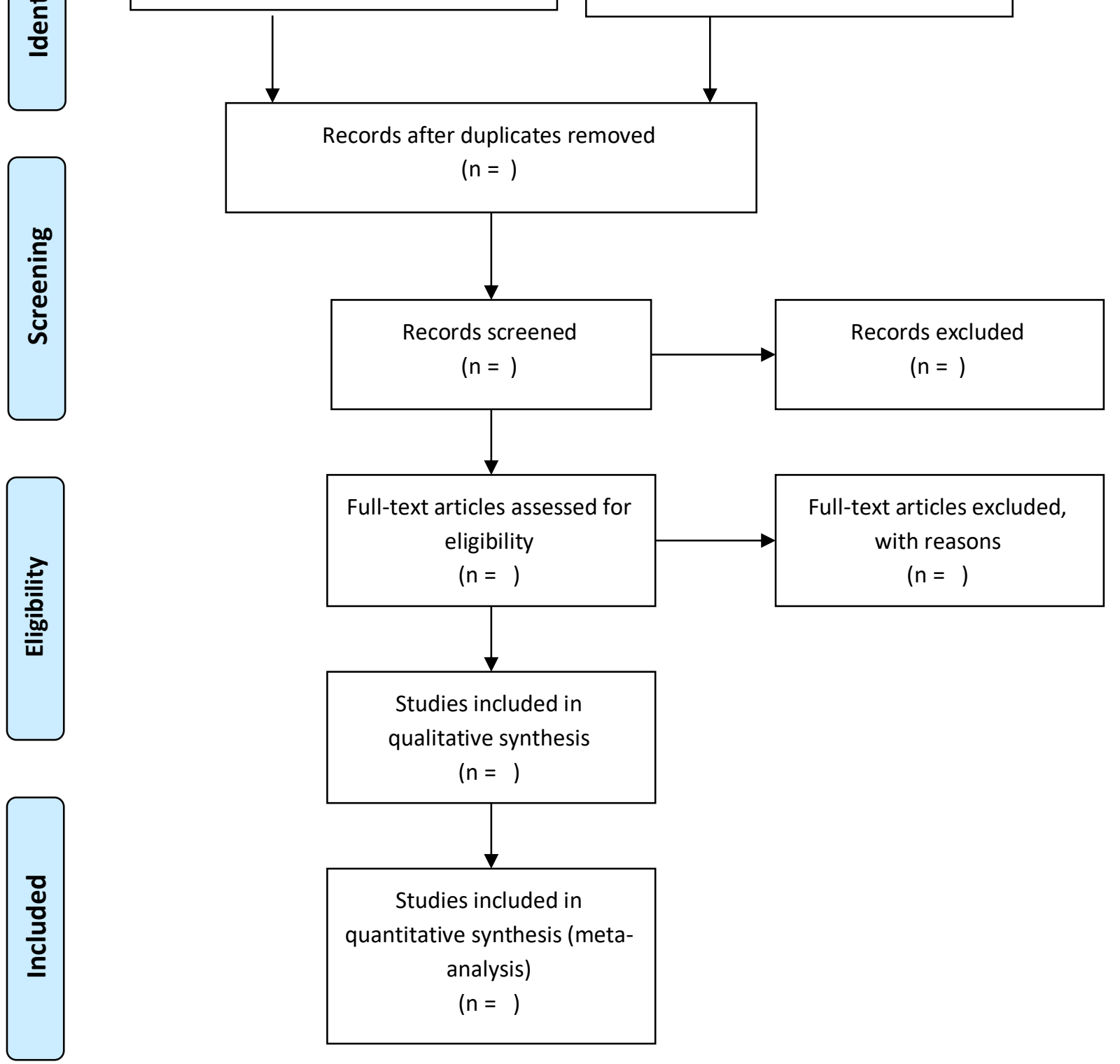

Studies included in qualitative synthesis $(n=)$

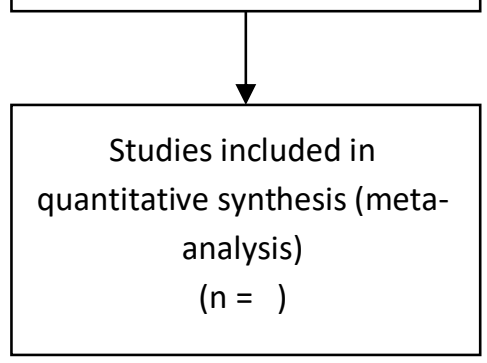

(Moher et al., 2009) 
Appendix F

\begin{tabular}{|c|c|c|c|c|}
\hline & 11 Questions & Yes & $\begin{array}{l}\text { Can't } \\
\text { tell }\end{array}$ & no \\
\hline 1 & Did the trial address a clearly focused issue? & & & \\
\hline 2 & Was the assignment of patients to treatments randomized? & & & \\
\hline 3 & $\begin{array}{l}\text { Were all the patients who entered the trial properly accounted for at } \\
\text { its conclusion? }\end{array}$ & & & \\
\hline 4 & $\begin{array}{l}\text { Were patients, health workers and study personnel 'blind" to } \\
\text { treatment? }\end{array}$ & & & \\
\hline 5 & Were the groups similar at the start of the trial? & & & \\
\hline 6 & $\begin{array}{l}\text { Aside from the experimental intervention, were the groups treated } \\
\text { equally? }\end{array}$ & & & \\
\hline 7 & How large was the treatment effect? & & & \\
\hline 8 & How precise was the estimate of the treatment effect? & & & \\
\hline 9 & $\begin{array}{l}\text { Can the results be applied in your context? (or to the local } \\
\text { population?) }\end{array}$ & & & \\
\hline 10 & Were all clinically important outcomes considered? & & & \\
\hline 11 & Are the benefits worth the harms and costs? & & & \\
\hline
\end{tabular}

(CASP, 2018) 


\section{Appendix G}

\section{Table 1}

Valasareddy, S. K., Titu, O. G., Anil, P. R., Segaran, S. K., George, S. K., \& Ranjan, R. V. (2018). Recovery profile using modified Aldrete score in post anaesthesia care unit after sevoflurane or desflurane anaesthesia: A prospective 51 andomized study. Journal of Clinical \& Diagnostic Research, 12(9), 1-4. https://doiorg.ric.idm.oclc.org/10.7860/JCDR/2018/35345.11963

\begin{tabular}{|c|c|c|c|}
\hline Purpose & Setting & Sample & Design Method \\
\hline $\begin{array}{l}\text {-To compare the } \\
\text { recovery profile of } \\
\text { desflurane and } \\
\text { sevoflurane using } \\
\text { MAS in immediate } \\
\text { postoperative } \\
\text { period in PACU } \\
\text { following anesthetic } \\
\text { duration of } 90-120 \\
\text { minutes }\end{array}$ & $\begin{array}{l}\text {-Obtained } \\
\text { Institutional Ethical } \\
\text { Committee } \\
\text { Approval } \\
\text {-Conducted at one } \\
\text { hospital }\end{array}$ & $\begin{array}{l}-60 \text { patients, ages } 18- \\
60 \\
\text {-ASA I or II }\end{array}$ & $\begin{array}{l}\text { Participants were } \\
\text { randomized into two } \\
\text { groups: those } \\
\text { receiving general } \\
\text { anesthesia with } \\
\text { sevoflurane and those } \\
\text { receiving general } \\
\text { anesthesia with } \\
\text { desflurane } \\
\text {-Patients randomized } \\
\text { by computer generator }\end{array}$ \\
\hline
\end{tabular}

\section{Table 2}

\begin{tabular}{|c|c|c|c|}
\hline $\begin{array}{l}\text { Type of Surgical } \\
\text { Procedure }\end{array}$ & $\begin{array}{l}\text { Recovery Scale } \\
\text { Used }\end{array}$ & Results & Limitations \\
\hline $\begin{array}{l}\text { - Elective surgical } \\
\text { procedures } \\
\text { requiring general } \\
\text { anesthesia with } \\
\text { endotracheal } \\
\text { intubation }\end{array}$ & $\begin{array}{l}\text {-Eye opening on } \\
\text { verbal command } \\
\text {-Modified Aldrete } \\
\text { Score (MAS) }\end{array}$ & $\begin{array}{l}\text {-Time for spontaneous eye } \\
\text { opening on verbal } \\
\text { commands in desflurane } \\
\text { group was } 5.17 \text { minutes } \\
\text { compared to sevoflurane } \\
\text { group which was } 8.96 \\
\text { minutes }(p<0.001) \\
\text {-Median MAS of } 10 \text { was } \\
\text { attained at five minutes in } \\
\text { desflurane group and } 15 \\
\text { minutes in sevoflurane } \\
\text { group ( }<<0.001)\end{array}$ & -None stated \\
\hline
\end{tabular}




\section{$\underline{\text { Table } 1}$}

Sezen, Ö., \& Bombacı, E. (2018). Comparison of early postoperative recovery after desflurane or sevoflurane anesthesia. Southern Clinics of Istanbul Eurasia, 29(3), 161-167. https://doi-org.ric.idm.oclc.org/10.14744/scie.2018.44265

\begin{tabular}{|l|l|l|l|}
\hline Purpose & Setting & Sample & Design Method \\
\hline $\begin{array}{l}\text {-To compare the } \\
\text { recovery profile of } \\
\text { patients who were } \\
\text { given sevoflurane and } \\
\text { desflurane }\end{array}$ & $\begin{array}{l}\text {-Received the } \\
\text { approval of the } \\
\text { local ethics } \\
\text { committee }\end{array}$ & $\begin{array}{l}-80 \text { patients ages 18-75 } \\
\text { with ASA status I or II }\end{array}$ & $\begin{array}{l}\text {-Patients were } \\
\text { allocated into 2 } \\
\text { groups using a } \\
\text { simple } \\
\text { randomization } \\
\text { method. }\end{array}$ \\
& & & $\begin{array}{l}\text { Premedication } \\
\text { was not given. }\end{array}$ \\
\hline
\end{tabular}

\section{$\underline{\text { Table } 2}$}

\begin{tabular}{|l|l|l|l|}
\hline $\begin{array}{l}\text { Type of } \\
\text { Surgial } \\
\text { Procedure }\end{array}$ & $\begin{array}{l}\text { Recovery } \\
\text { Scale Used }\end{array}$ & \multicolumn{1}{|c|}{ Results } & Limitations \\
\hline $\begin{array}{l}\text {-lower } \\
\text { abdominal } \\
\text { surgery } \\
\text { requiring } \\
\text { general } \\
\text { anesthesia } \\
\text { with } \\
\text { endotracheal } \\
\text { intubation }\end{array}$ & $\begin{array}{l}\text {-Aldrete } \\
\text { Score during } \\
\text { the post- } \\
\text { operative } \\
\text { period } \\
\text {-Pain } \\
\text { evaluation } \\
\text { performed } \\
\text { using a } \\
\text { visual } \\
\text { analog scale } \\
\text { (VAS) of } 1-\end{array}$ & $\begin{array}{l}\text {-The Modified Aldrete Score in the } \\
\text { desflurane group was significantly } \\
\text { hinger than the sevoflurane group at } 10 \\
\text { minutes and later intervals }(\mathrm{p}<0.002) \\
\text {-The desflurane group also had } \\
\text { significantly higher SpO2 values than } \\
\text { those in the sevoflurane group }(\mathrm{p}<0.05 \\
\text { and above) at 10, 20, 30, and 45 } \\
\text { minutes. }\end{array}$ & -None stated \\
10 & & & \\
& & & \\
& & & \\
& & & \\
\end{tabular}

\section{Appendix I}

\section{Table 1}


Pakpirom, J., Kraithep, J., \& Pattaravit, N. (2016). Length of postanesthetic care unit stay in elderly patients after general anesthesia: A randomized controlled trial comparing desflurane and sevoflurane. Journal Of Clinical Anesthesia, 32, 294299. https://doi-org.ric.idm.oclc.org/10.1016/j.jclinane.2015.08.016

\begin{tabular}{|l|l|l|l|}
\hline Purpose & Setting & Sample & Design Method \\
\hline $\begin{array}{l}\text {-To compare the } \\
\text { length of PACU stay } \\
\text { and recovery profiles } \\
\text { of elderly patients } \\
\text { after general } \\
\text { anesthesia between } \\
\text { sevoflurane and } \\
\text { desflurane }\end{array}$ & $\begin{array}{l}\text {-Tertiary care } \\
\text { hospital: } \\
\text { Songklanagarind } \\
\text { Hospital } \\
\text {-Received approval } \\
\text { from the Ethics } \\
\text { committee }\end{array}$ & $\begin{array}{l}\text {-80 elderly } \\
\text { patients older than } \\
\text { age 65 } \\
\text {-ASA status I, II, } \\
\text { or III }\end{array}$ & $\begin{array}{l}\text {-Randomized, } \\
\text { double-blind, } \\
\text { controlled clinical } \\
\text { trial } \\
\text {-Randomly } \\
\text { allocated into 2 } \\
\text { groups: } \\
\text { sevoflurane group } \\
\text { (n=38) and } \\
\text { desflurane group } \\
\text { (n=42) }\end{array}$ \\
\hline
\end{tabular}

Table 2

\begin{tabular}{|l|l|l|l|}
\hline $\begin{array}{l}\text { Type of Surgical } \\
\text { Procedure }\end{array}$ & $\begin{array}{l}\text { Recovery Scale } \\
\text { Used }\end{array}$ & Results & Limitations \\
\hline
\end{tabular}




\begin{tabular}{|c|c|c|c|}
\hline $\begin{array}{l}\text {-Non-emergency } \\
\text { surgery under } \\
\text { general anesthesia } \\
\text { with endotracheal } \\
\text { tube }\end{array}$ & $\begin{array}{l}\text {-length of PACU } \\
\text { stay was recorded } \\
\text { as the primary } \\
\text { outcome } \\
\text {-Time to open } \\
\text { eyes, time to } \\
\text { follow commands, } \\
\text { and time to } \\
\text { extubation were } \\
\text { assessed }\end{array}$ & $\begin{array}{l}\text {-length of PACU stay was not } \\
\text { significantly different in the } \\
\text { patients who recovered from } \\
\text { sevoflurane ( } 49.4 \text { minutes) or } \\
\text { desflurane ( } 50.1 \text { minutes) } \\
\text { general anesthesia } \\
\text {-Desflurane was associated } \\
\text { with faster early recovery then } \\
\text { sevoflurane measured by time } \\
\text { to open eyes ( } 7.5 \text { vs. } 9.6 \\
\text { minutes) and time to follow } \\
\text { commands ( } 9.0 \text { vs } 11.2 \\
\text { minutes), with p values }=0.04 \\
\text { and } 0.05 \text { respectively. } \\
\text {-Length of PACU stay was } \\
\text { similar in both groups, but } \\
\text { desflurane group was } \\
\text { associated with a faster early } \\
\text { recovery than sevoflurane } \\
\text { group }\end{array}$ & $\begin{array}{l}\text {-small } \\
\text { sample } \\
\text { size }\end{array}$ \\
\hline
\end{tabular}

\section{Appendix J}

\section{$\underline{\text { Table } 1}$}

McKay, R. E., Hall, K. T., \& Hills, N. (2016). The effect of anesthetic choice (sevoflurane versus desflurane) and neuromuscular management on speed of 
airway reflex recovery. Anesthesia And Analgesia, 122(2), 393-401. https://doiorg.ric.idm.oclc.org/10.1213/ANE.0000000000001022

\begin{tabular}{|l|l|l|l|}
\hline Purpose & Setting & Sample & Design Method \\
\hline $\begin{array}{l}\text {-To investigate if } \\
\text { paralyzed and } \\
\text { intubated patients' } \\
\text { recovery of airway } \\
\text { reflexes would be } \\
\text { slower with } \\
\text { sevoflurane than } \\
\text { desflurane }\end{array}$ & $\begin{array}{l}\text {-Exact location(s) } \\
\text { not specified } \\
-33 \text { anesthesiologist } \\
\text { faculty members, } \\
17 \text { CRNAs, and } 11\end{array}$ & $\begin{array}{l}\text {-81 ASA I and } \\
\text { II patients ages } \\
18-65 \text { with a } \\
\text { body max index } \\
(\mathrm{BMI})<35\end{array}$ & $\begin{array}{l}\text {-patients randomly } \\
\text { assigned to one of } \\
\text { two groups: } \\
\text { sevoflurane }(\mathrm{n}= \\
\text { in patient care } \\
\mathrm{kg} / \mathrm{m} 2\end{array}$ \\
& $\begin{array}{l}\mathrm{n}=40) \\
\text {-Average time } \\
\text { intervals were } \\
\text { compared between } \\
\text { the two groups. }\end{array}$ \\
\hline
\end{tabular}

Table 2

\begin{tabular}{|l|l|l|l|}
\hline $\begin{array}{l}\text { Type of } \\
\text { Surgical } \\
\text { Procedure }\end{array}$ & Recovery Scale Used & Results & Limitations \\
\hline
\end{tabular}




\begin{tabular}{|c|c|c|c|}
\hline $\begin{array}{l}\text {-specific } \\
\text { procedures } \\
\text { not } \\
\text { identified } \\
\text {-surgical } \\
\text { procedures } \\
\text { requiring 2- } \\
3 \text { hour } \\
\text { duration } \\
\text { requiring } \\
\text { general } \\
\text { anesthesia } \\
\text { with } \\
\text { intubation } \\
\text { and muscle } \\
\text { relaxation }\end{array}$ & $\begin{array}{l}\text {-Time of first response } \\
\text { was noted } \\
\text {-Patients were then } \\
\text { given a } 20 \mathrm{~mL} \text { water } \\
\text { swallow test at } 2,6,14 \text {, } \\
22,30 \text {, and } 60 \text { minutes } \\
\text {-Time intervals } \\
\text { consisted of : T1.) } \\
\text { discontinuation of } \\
\text { anesthetic to first } \\
\text { response to command, } \\
\text { T2.) first response to } \\
\text { first successful swallow } \\
\text { test, T3.) anesthetic } \\
\text { discontinuation to first } \\
\text { successful swallow test } \\
\text {-All those who were } \\
\text { unable to take the test at } \\
2 \text { minutes were deemed } \\
\text { failures. Ten patients } \\
\text { were unable to take the } \\
\text { test at } 2 \text { minutes due to } \\
\text { somnolence. }\end{array}$ & $\begin{array}{l}\text {-Patients } \\
\text { receiving } \\
\text { desflurane passed } \\
\text { the swallowing } \\
\text { test at shorter } \\
\text { time intervals } \\
\text { after first } \\
\text { response to } \\
\text { command than } \\
\text { the sevoflurane } \\
\text { patients (p = } \\
\text { 0.054) } \\
\text {-Overall, } \\
\text { desflurane group } \\
\text { had faster } \\
\text { recover or airway } \\
\text { reflexes }\end{array}$ & $\begin{array}{l}\text {-The lack of uniform } \\
\text { adherence to protocol } \\
\text { makes a definitive } \\
\text { association between } \\
\text { volatile and outcome } \\
\text { difficult to establish } \\
\text {-Airway reflex status of } \\
\text { patients who are not } \\
\text { tested can not be } \\
\text { determined with } \\
\text { certainty. The authors } \\
\text { feel that considering } \\
\text { patients who were too } \\
\text { somnolent to participate } \\
\text { in the swallow test as } \\
\text { failures. }\end{array}$ \\
\hline
\end{tabular}

\section{Appendix K}

\section{$\underline{\text { Table } 1}$}

Gökçek, E., Kaydu, A., Akdemir, M. S., Akil, F., \& Akınc1, I. O. (2016). Early postoperative recovery after intracranial surgical procedures. Comparison of the 
effects of sevoflurane and desflurane. Acta Cirurgica Brasileira, 31(9), 638-644. https://doi-org.ric.idm.oclc.org/10.1590/S0102-865020160090000010

\begin{tabular}{|l|l|l|l|}
\hline Purpose & Setting & Sample & Design Method \\
\hline $\begin{array}{l}\text {-To compare the } \\
\text { effects of } \\
\text { sevoflurane and } \\
\text { desflurane on early } \\
\text { anesthesia } \\
\text { recovery }\end{array}$ & $\begin{array}{l}\text {-IRB approval was } \\
\text { received and ethics } \\
\text { committee }\end{array}$ & $\begin{array}{l}\text {-Performed at a } \\
\text { aged 18-70 } \\
\text { medical facility at the } \\
\text { Istanbul University } \\
\text { neurosurgery clinics } \\
\text { between February and } \\
\text { May 2011 }\end{array}$ & $\begin{array}{l}\text {-Patients randomly } \\
\text { divided into 2 } \\
\text { groups: sevoflurane } \\
\text { and desflurane- } \\
\text { Prospective, double- } \\
\text { blinded, randomized } \\
\text { study } \\
\text {-Sevoflurane group } \\
=25, \text { desflurane } \\
\text { group = 25 patients }\end{array}$ \\
& & & \\
\hline
\end{tabular}

Table 2

\begin{tabular}{|l|l|l|l|}
\hline $\begin{array}{l}\text { Type of Surgical } \\
\text { Procedure }\end{array}$ & Recovery Scale Used & Results & Limitations \\
\hline
\end{tabular}




\begin{tabular}{|c|c|c|c|}
\hline $\begin{array}{l}\text {-Craniotomy for } \\
\text { intracranial } \\
\text { lesions }\end{array}$ & $\begin{array}{l}\text {-Patients were evaluated } \\
\text { post-operatively for } \\
\text { responses to painful stimuli, } \\
\text { eye opening, hand squeezing, } \\
\text { extubation, orientation and } \\
\text { time required to achieve a } \\
\text { Modified Aldrete Score } \\
\text { (MAS) of 9-10 } \\
\text {-Spatial, temporal, and } \\
\text { personal orientation }\end{array}$ & $\begin{array}{l}\text {-Times to } \\
\text { responses to } \\
\text { painful stimuli ( } p \\
<0.001) \text {, } \\
\text { emergence } \\
(p<0.001) \text {, hand- } \\
\text { squeezing } \\
(p<0.001) \text {, } \\
\text { extubation } \\
(p<0.001) \text {, } \\
\text { orientation } \\
\text { ( }<<0.001) \text { and } \\
\text { Aldrete score of } \\
9-10 \text { ( } p<0.001) \\
\text { were } \\
\text { significantly } \\
\text { lower with the } \\
\text { desflurane group } \\
\text { versus the } \\
\text { sevoflurane } \\
\text { group. } \\
\text {-All } 50 \text { patients } \\
\text { completed the } \\
\text { study }\end{array}$ & -None stated \\
\hline
\end{tabular}

\section{Appendix L}

\section{Table 1}


Gangakhedkar, G., \& Monteiro, J. (2019). A prospective randomized double-blind study to compare the early recovery profiles of desflurane and sevoflurane in patients undergoing laparoscopic cholecystectomy. Journal of Anaesthesiology Clinical Pharmacology, 35(1), 53-57. https://doiorg.ric.idm.oclc.org/10.4103/joacp.JOACP_375_17

\begin{tabular}{|l|l|l|l|}
\hline Purpose & Setting & Sample & Design Method \\
\hline $\begin{array}{l}\text {-To compare the early } \\
\text { recovery profiles of } \\
\text { sevoflurane and } \\
\text { desflurane in patients } \\
\text { undergoing } \\
\begin{array}{l}\text { laparoscopic } \\
\text { cholecystectomy }\end{array}\end{array}$ & $\begin{array}{l}\text {-Received } \\
\text { approval from } \\
\text { the } \\
\text { Institutional } \\
\text { Ethics } \\
\text { Committee }\end{array}$ & $\begin{array}{l}\text {-60 ASA } \\
\text { class I and } \\
\text { II patients } \\
\text { between } \\
\text { the ages of } \\
20 \text { and } 60 \\
\text { years }\end{array}$ & $\begin{array}{l}\text {-Patients were randomly } \\
\text { assigned by computer } \\
\text { generated table to receive } \\
\text { desflurane (n=30) or } \\
\text { sevoflurane }(\mathrm{n}=30) \text { using BIS } \\
\text { to determine depth of } \\
\text { anesthesia } \\
\text {-Randomized controlled } \\
\text { double-blind study }\end{array}$ \\
\hline
\end{tabular}

\section{Table 2}




\begin{tabular}{|c|c|c|c|}
\hline $\begin{array}{l}\text { Type of Surgical } \\
\text { Procedure }\end{array}$ & Recovery Scale Used & Results & Limitations \\
\hline $\begin{array}{l}\text {-Laparoscopic } \\
\text { cholecystectomy }\end{array}$ & $\begin{array}{l}\text {-Time required for } \\
\text { extubation, eye } \\
\text { opening, verbal } \\
\text { response and } \\
\text { achievement of a } \\
\text { modified Aldrete } \\
\text { score of } 9\end{array}$ & $\begin{array}{l}\text {-The time to extubation, } \\
\text { eye opening, and verbal } \\
\text { response were shorter in } \\
\text { the desflurane group } \\
\text {-The time required for } \\
\text { extubation and for eye } \\
\text { opening was } \\
\text { significantly shorter in } \\
\text { the desflurane group } \\
\text { compared to the } \\
\text { sevoflurane group (p = } \\
0.049 \text { and } 0.008 \text {, } \\
\text { respectively) } \\
\text {-A higher mean modified } \\
\text { Aldrete score was seen at } \\
\text { extubation in the } \\
\text { desflurane group } \\
\text { (p<0.001) } \\
\text {-Desflurane group } \\
\text { achieved a modified } \\
\text { Aldrete score of } 9 \text { sooner } \\
\text { than sevoflurane group }\end{array}$ & $\begin{array}{l}\text {-Patient } \\
\text { population did } \\
\text { not include } \\
\text { geriatric } \\
\text { patients or } \\
\text { obese patients }\end{array}$ \\
\hline
\end{tabular}


Valasareddy, S. K., Titu, O. G., Anil, P. R., Segaran, S. K., George, S. K., \& Ranjan, R. V. (2018). Recovery profile using modified Aldrete score in post anaesthesia care unit after sevoflurane or desflurane anaesthesia: A prospective 61 andomized study. Journal of Clinical \& Diagnostic Research, 12(9), 1-4. https://doiorg.ric.idm.oclc.org/10.7860/JCDR/2018/35345.11963

\begin{tabular}{|c|c|c|c|c|}
\hline & & Yes & $\begin{array}{l}\text { Can't } \\
\text { Tell }\end{array}$ & No \\
\hline 1 & $\begin{array}{l}\text { Did the trial address a clearly focused issue? To assess } \\
\text { the efficacy of sevoflurane and desflurane with regards to } \\
\text { emergence and recovery in surgical patients undergoing } \\
\text { general anesthesia. }\end{array}$ & $X$ & & \\
\hline 2 & $\begin{array}{l}\text { Was the assignment of patients to treatments } \\
\text { randomized? Patients were randomized by computer } \\
\text { generated numbers into two groups of } 30 \text { each to receive } \\
\text { either desflurane or sevoflurane. }\end{array}$ & $\mathrm{X}$ & & \\
\hline 3 & $\begin{array}{l}\text { Were all the patients who entered the trial properly } \\
\text { accounted for at its conclusion? All } 60 \text { patients who } \\
\text { began the study completed the assessment as of protocol. }\end{array}$ & $X$ & & \\
\hline 4 & $\begin{array}{l}\text { Were patients, health workers and study personnel } \\
\text { 'blind' to treatment? The study does not mention whether } \\
\text { or not patients, healthcare workers, and study personnel } \\
\text { were blind to treatment. }\end{array}$ & & $\mathrm{X}$ & \\
\hline 5 & $\begin{array}{l}\text { Were the groups similar at the start of the trial? The } \\
\text { sample consisted of patients ages } 18-60 \text { who were all ASA } \\
\text { class I or II undergoing elective procedures requiring } \\
\text { endotracheal intubation. A thorough preoperative } \\
\text { assessment was performed and patients with severe organ } \\
\text { dysfunction, psychiatric illness, morbid obesity, current } \\
\text { pregnancy, or drug allergy were excluded. }\end{array}$ & $X$ & & \\
\hline 6 & $\begin{array}{l}\text { Aside from the experimental intervention, were the } \\
\text { groups treated equally? All patients were NPO for } 6 \\
\text { hours prior to surgery and routine aspiration prophylaxis } \\
\text { was given. All patients received the same IV medications } \\
\text { based on body weight and were monitored equally. }\end{array}$ & $X$ & & \\
\hline 7 & $\begin{array}{l}\text { How large was the treatment effect? Time to eye opening } \\
\text { on verbal command was faster in the desflurane group }(p= \\
<0.001) \text {. At one minute the MAS was insignificant } \\
(p>0.05) \text {. A median score of } 10 \text { was attained at } 5 \text { minutes } \\
\text { by desflurane and } 15 \text { minutes by sevoflurane which was } \\
\text { statistically significant }(p<0.001)\end{array}$ & $X$ & & \\
\hline
\end{tabular}




\begin{tabular}{|c|c|c|}
\hline 8 & $\begin{array}{l}\text { How precise was the estimate of the treatment effect? } \\
\text { Time to spontaneous eye opening on verbal command was } \\
\text { significantly faster in the desflurane group clinically and } \\
\text { statistically significant with a } p<0.001 \text { and a confidence } \\
\text { interval } 3.7\end{array}$ & $\mathrm{X}$ \\
\hline 9 & $\begin{array}{l}\text { Can the results be applied in your context? (or to the } \\
\text { local population?) Findings were appropriate for this } \\
\text { systematic review }\end{array}$ & $\mathrm{X}$ \\
\hline 10 & $\begin{array}{l}\text { Were all clinically important outcomes considered? Eye } \\
\text { opening and MAS at arrival in PACU, after 5, 10, and } 15 \\
\text { minutes were recorded. }\end{array}$ & $X$ \\
\hline 11 & $\begin{array}{l}\text { Are the benefits worth the harms and costs? No patient } \\
\text { had adverse effects }\end{array}$ & $\mathrm{X}$ \\
\hline
\end{tabular}

\section{Appendix N}


Sezen, Ö., \& Bombac1, E. (2018). Comparison of early postoperative recovery after desflurane or sevoflurane anesthesia. Southern Clinics of Istanbul Eurasia, 29(3), 161-167. https://doi-org.ric.idm.oclc.org/10.14744/scie.2018.44265

\begin{tabular}{|c|c|c|c|c|}
\hline & Question & Yes & $\begin{array}{l}\text { Can't } \\
\text { Tell }\end{array}$ & No \\
\hline 1 & $\begin{array}{l}\text { Did the trial address a clearly focused issue? To } \\
\text { compare the early postoperative recovery effects between } \\
\text { patients having lower abdominal surgery who were given } \\
\text { sevoflurane or desflurane during general anesthesia }\end{array}$ & $X$ & & \\
\hline 2 & $\begin{array}{l}\text { Was the assignment of patients to treatments } \\
\text { randomized? Patients were allocated into two groups } \\
\text { using a simple randomization method. }\end{array}$ & $X$ & & \\
\hline 3 & $\begin{array}{l}\text { Were all of the patients who entered the trial properly } \\
\text { accounted for at its conclusion? The article states that } 80 \\
\text { patients were chosen for this study, but does not clearly } \\
\text { state that } 80 \text { patients finished. }\end{array}$ & & $X$ & \\
\hline 4 & $\begin{array}{l}\text { Were patients, health workers and study personnel } \\
\text { blinded? Whether or not patients, healthcare workers, and } \\
\text { study personnel were blinded is not mentioned in the } \\
\text { article. }\end{array}$ & & $\mathrm{X}$ & \\
\hline 5 & $\begin{array}{l}\text { Were the groups similar at the start of the trial? Patients } \\
\text { were ASA status class I or II. None were premedicated. } \\
\text { The ages of group one ranged from } 20 \text { to } 60 \text { years old. } \\
\text { Group two ranged from } 19 \text { to } 69 \text { years. Body weight was } \\
\text { similar among the two groups. }\end{array}$ & $X$ & & \\
\hline 6 & $\begin{array}{l}\text { Aside from the experimental intervention, were the } \\
\text { groups treated equally? Vital signs and neuromuscular } \\
\text { blockade were monitored similarly between the two } \\
\text { groups. Intubation time, medications administered, } \\
\text { air/oxygen mixture, and MAC among the two gasses were } \\
\text { similar among both groups. }\end{array}$ & $X$ & & \\
\hline 7 & $\begin{array}{l}\text { How large was the treatment effect? No statistically } \\
\text { significant differences were seen in the groups in terms of } \\
\text { time to extubation } p>0.05 \text { or time to eye opening on verbal } \\
\text { command } p>0.05 \text {. As far as the Aldrete Scores, the } \\
\text { desflurane goup had higher scores at } 10 \text { minutes and } \\
\text { afterwards. At } 10 \text { minutes } p=0.0145 \text {, which was significant. }\end{array}$ & $X$ & & \\
\hline 8 & $\begin{array}{l}\text { How precise was the estimate of the treatment effect? } \\
\text { This is not discussed. }\end{array}$ & & $X$ & \\
\hline 9 & $\begin{array}{l}\text { Can the results be applied in your context? (Or to the } \\
\text { local population?) Findings were appropriate for this } \\
\text { systematic review. }\end{array}$ & $\mathrm{X}$ & & \\
\hline
\end{tabular}




\begin{tabular}{|l|l|l|l|l|}
\hline 10 & $\begin{array}{l}\text { Were all clinically important outcomes considered? } \\
\text { Aldrete score, length of time to extubation, vital signs, } \\
\text { airway control, and visual analogue scale scores were all } \\
\text { recorded. }\end{array}$ & $\mathrm{X}$ & & \\
\hline $\mathbf{1 1}$ & $\begin{array}{l}\text { Are the benefits worth the harms and costs? No harm } \\
\text { was noted. Cost analysis was not discussed. }\end{array}$ & $\mathrm{X}$ & \\
\hline
\end{tabular}


Pakpirom, J., Kraithep, J., \& Pattaravit, N. (2016). Length of postanesthetic care unit stay in elderly patients after general anesthesia: A randomized controlled trial comparing desflurane and sevoflurane. Journal Of Clinical Anesthesia, 32, 294 299. https://doi-org.ric.idm.oclc.org/10.1016/j.jclinane.2015.08.016

\begin{tabular}{|c|c|c|c|c|}
\hline & Question & Yes & $\begin{array}{l}\text { Can't } \\
\text { Tell }\end{array}$ & No \\
\hline 1 & $\begin{array}{l}\text { Did the trial address a clearly focused issue? To compare } \\
\text { the length of PACU stay and recovery profiles of elderly } \\
\text { patients after general anesthesia with desflurane or } \\
\text { sevoflurane. }\end{array}$ & $X$ & & \\
\hline 2 & $\begin{array}{l}\text { Was the assignment of patients to treatments } \\
\text { randomized? Patients were randomly allocated into one of } \\
\text { two groups. }\end{array}$ & $X$ & & \\
\hline 3 & $\begin{array}{l}\text { Were all of the patients who entered the trial properly } \\
\text { accounted for at its conclusion? } 80 \text { patients began the trial, } \\
\text { but two patients from the sevoflurane group were excluded } \\
\text { because of the length of their procedure and need to be } \\
\text { intubated postoperatively. }\end{array}$ & $X$ & & \\
\hline 4 & $\begin{array}{l}\text { Were patients, health workers and study personnel } \\
\text { blinded? This study was double-blinded, but } \\
\text { anesthesiologists and nurse anesthetist were not blinded } \\
\text { because they needed to adjust the gasses to maintain an } \\
\text { adequate depth of anesthesia. }\end{array}$ & & & $X$ \\
\hline 5 & $\begin{array}{l}\text { Were the groups similar at the start of the trial? ASA } \\
\text { class II and III patients were chosen. All patients were } 65 \\
\text { years or older, and those with significant comorbidities were } \\
\text { excluded. Type of surgery and anticipated length were } \\
\text { similar among the patients. }\end{array}$ & $\mathrm{X}$ & & \\
\hline 6 & $\begin{array}{l}\text { Aside from the experimental intervention, were the } \\
\text { groups treated equally? Patients received no sedative } \\
\text { medication preoperatively. Monitoring including BIS } \\
\text { monitoring was similar among the groups. Fluid } \\
\text { administration and medications were similar. MAC of } \\
\text { anesthetic agent and air with } 40 \% \text { oxygen were administered. } \\
\text { Anesthetic agent was turned off at the end of skin closure. }\end{array}$ & $X$ & & \\
\hline 7 & $\begin{array}{l}\text { How large was the treatment effect? Patients in the } \\
\text { desflurane group recovered significantly faster than the } \\
\text { patients in the sevoflurane group as indicated by the time to } \\
\text { open eyes ( } 7.5 \text { verses } 9.6 \text { minutes) and time to follow } \\
\text { commands ( } 9.0 \text { and } 11.2 \text { minutes). Time to eye opening had } \\
\text { a P value of } 0.04 \text { and time to follow commands had a P value } \\
\text { of } 0.05 \text {. }\end{array}$ & $X$ & & \\
\hline
\end{tabular}




\begin{tabular}{|l|l|l|l|}
\hline $\mathbf{8}$ & $\begin{array}{l}\text { How precise was the estimate of the treatment effect? } \\
\text { This was not mentioned. }\end{array}$ & $\mathrm{X}$ \\
\hline $\mathbf{9}$ & $\begin{array}{l}\text { Can the results be applied in your context? (Or to the } \\
\text { local population?) Findings were appropriate for this } \\
\text { systematic review. }\end{array}$ & $\mathrm{X}$ & $\begin{array}{l}\text { Were all clinically important outcomes considered? Time } \\
\text { to eye opening, time to follow commands, and exbutation } \\
\text { time were all recorded. Fentanyl consumption, PACU stay, } \\
\text { type and time of procedure were all recorded. }\end{array}$ \\
\hline $\mathbf{1 1}$ & $\begin{array}{l}\text { Are the benefits worth the harms and costs? No harm or } \\
\text { costs were discussed in this article. }\end{array}$ & $\mathrm{X}$ & \\
\hline
\end{tabular}


McKay, R. E., Hall, K. T., \& Hills, N. (2016). The effect of anesthetic choice (sevoflurane versus desflurane) and neuromuscular management on speed of airway reflex recovery. Anesthesia And Analgesia, 122(2), 393-401. https://doiorg.ric.idm.oclc.org/10.1213/ANE.0000000000001022

\begin{tabular}{|c|c|c|c|c|}
\hline & Question & Yes & $\begin{array}{c}\text { Can't } \\
\text { Tell }\end{array}$ & $\overline{N o}$ \\
\hline 1 & $\begin{array}{l}\text { Did the trial address a clearly focused issue? To see if } \\
\text { there would be a significant difference in airway reflex } \\
\text { recovery between patients receiving desflurane or } \\
\text { sevoflurane, who also received rocuronium for } \\
\text { neuromuscular blockade. }\end{array}$ & $\mathrm{X}$ & & \\
\hline 2 & $\begin{array}{l}\text { Was the assignment of patients to treatments } \\
\text { randomized? Patients were randomly assigned to one of } \\
\text { two groups. }\end{array}$ & $X$ & & \\
\hline 3 & $\begin{array}{l}\text { Were all of the patients who entered the trial properly } \\
\text { accounted for at its conclusion? } 81 \text { patients were chosen } \\
\text { for this trial and all of them were accounted for at the end. }\end{array}$ & $X$ & & \\
\hline 4 & $\begin{array}{l}\text { Were patients, health workers and study personnel } \\
\text { blinded? The article states that the research technician } \\
\text { was blinded to the anesthetic gas used. The anesthesia } \\
\text { providers received an envelope with an assignment of the } \\
\text { randomization. }\end{array}$ & & & $\mathrm{X}$ \\
\hline 5 & $\begin{array}{l}\text { Were the groups similar at the start of the trial? ASA } \\
\text { class I and II patients aged } 18 \text { to } 65 \text { were chosen. BMIs } \\
\text { were all under } 35 \text {, and duration of surgery was anticipated } \\
\text { to be } 2-3 \text { hours duration. All patients were administered } \\
\text { and passed a swallow study prior to their scheduled } \\
\text { procedure. All patients received midazolam } \\
\text { preoperatively. }\end{array}$ & $X$ & & \\
\hline 6 & $\begin{array}{l}\text { Aside from the experimental intervention, were the } \\
\text { groups treated equally? Patients were monitored based } \\
\text { on ASA monitoring standards, administered the same } \\
\text { medication based on weight, with the same air/oxygen } \\
\text { combination. The only stated differences were in the } \\
\text { anesthetic gas randomly chosen, lower BMIs in the } \\
\text { desflurane group, and less MAC hours but more fentanyl } \\
\text { administered in the desflurane group. }\end{array}$ & $X$ & & \\
\hline 7 & $\begin{array}{l}\text { How large was the treatment effect? Time from } \\
\text { anesthetic discontinuation to first appropriate response to } \\
\text { command was shorter in the desflurane group ( } \mathrm{P}=0.0001) \text {. } \\
\text { Time to ability to swallow was also shorter in the } \\
\text { desflurane group }(\mathrm{P}=0.0007) \text {. }\end{array}$ & $X$ & & \\
\hline
\end{tabular}




\begin{tabular}{|c|c|c|c|}
\hline 8 & $\begin{array}{l}\text { How precise was the estimate of the treatment effect? } \\
\text { Confidence interval } 95 \%\end{array}$ & $X$ & \\
\hline 9 & $\begin{array}{l}\text { Can the results be applied in your context? (Or to the } \\
\text { local population?) This study is appropriate for this } \\
\text { systematic review. }\end{array}$ & $X$ & \\
\hline 10 & $\begin{array}{l}\text { Were all clinically important outcomes considered? } \\
\text { First appropriate response, ability to swallow after } \\
\text { discontinuation of anesthetic were recorded. Time from } \\
\text { first appropriate response to ability to swallow were also } \\
\text { recorded. Patients who were too somnolent to be tested } \\
\text { were recorded. }\end{array}$ & $\mathrm{X}$ & \\
\hline 11 & $\begin{array}{l}\text { Are the benefits worth the harms and costs? Harm to } \\
\text { patients and cost analysis were not discussed in this } \\
\text { article. }\end{array}$ & & $X$ \\
\hline
\end{tabular}


Gökçek, E., Kaydu, A., Akdemir, M. S., Akil, F., \& Akıncı, I. O. (2016). Early postoperative recovery after intracranial surgical procedures. Comparison of the effects of sevoflurane and desflurane. Acta Cirurgica Brasileira, 31(9), 638-644. https://doi-org.ric.idm.oclc.org/10.1590/S0102-865020160090000010

\begin{tabular}{|c|c|c|c|c|}
\hline & Question & Yes & $\begin{array}{l}\text { Can't } \\
\text { Tell }\end{array}$ & No \\
\hline 1 & $\begin{array}{l}\text { Did the trial address a clearly focused issue? To } \\
\text { compare the effects of sevoflurane verses desflurane in } \\
\text { patients undergoing craniotomy for intracranial lesions. }\end{array}$ & $\mathrm{X}$ & & \\
\hline 2 & $\begin{array}{l}\text { Was the assignment of patients to treatments } \\
\text { randomized? Patients were randomly divided into either } \\
\text { the sevoflurane or desflurane group. }\end{array}$ & $\mathrm{X}$ & & \\
\hline 3 & $\begin{array}{l}\text { Were all of the patients who entered the trial properly } \\
\text { accounted for at its conclusion? All } 50 \text { patients } \\
\text { completed the study. }\end{array}$ & $X$ & & \\
\hline 4 & $\begin{array}{l}\text { Were patients, health workers and study personnel } \\
\text { blinded? Patients and study coordinator were blinded } \\
\text { throughout the study. On the day of the surgery the } \\
\text { anesthesia providers opened an envelope that stores a } \\
\text { randomized number as to not change the patient's group. }\end{array}$ & & & $\mathrm{X}$ \\
\hline 5 & $\begin{array}{l}\text { Were the groups similar at the start of the trial? } \\
\text { Patients were ASA class I or II, ranged in age from 18-70 } \\
\text { years, with a GCS of } 15 \text { and scheduled craniotomy. } \\
\text { Patients with serious comorbidities were excluded. }\end{array}$ & $\mathrm{X}$ & & \\
\hline 6 & $\begin{array}{l}\text { Aside from the experimental intervention, were the } \\
\text { groups treated equally? Patients received IV fluids } \\
\text { based on ideal body weight and did not receive IV } \\
\text { sedation preoperatively. Monitoring including a bladder } \\
\text { catheter for temperature monitoring and train of four for } \\
\text { neuromuscular blockade was done for every patient. } \\
\text { Patients were administered the same medication based on } \\
\text { body weight. Arterial lines and central venous pressure } \\
\text { lines were also monitored on every patient in the study. } \\
\text { Patients were treated for hypotension and bradycardia if } \\
\text { needed. }\end{array}$ & $\mathrm{X}$ & & \\
\hline 7 & $\begin{array}{l}\text { How large was the treatment effect? The times to } \\
\text { respond to a painful stimulus, interval from eye opening } \\
\text { to command, and times to extubation, handgrip, } \\
\text { orientation and achievement of an Aldrete score of } 9-10 \\
\text { were found to be significantly shorter in the desflurane } \\
\text { group }(\mathrm{p}<0.001)\end{array}$ & $\mathrm{X}$ & & \\
\hline
\end{tabular}




\begin{tabular}{|l|l|l|l|l|}
\hline $\mathbf{8}$ & $\begin{array}{l}\text { How precise was the estimate of the treatment effect? } \\
\text { This is not discussed. }\end{array}$ & & \\
\hline $\mathbf{9}$ & $\begin{array}{l}\text { Can the results be applied in your context? (Or to the } \\
\text { local population?) This study is relevant to this } \\
\text { systematic review. }\end{array}$ & $\mathrm{X}$ & & \\
\hline $\mathbf{1 0}$ & $\begin{array}{l}\text { Were all clinically important outcomes considered? } \\
\text { Yes. Times to respond to emergence, painful stimulus, } \\
\text { handgrip, extubation, and orientation are studied. Time } \\
\text { to Modified Aldrete Score of 9-10 was also compared. }\end{array}$ & $\mathrm{X}$ & & \\
\hline $\mathbf{1 1}$ & $\begin{array}{l}\text { Are the benefits worth the harms and costs? This was } \\
\text { not discussed. }\end{array}$ & $\mathrm{X}$ & \\
\hline
\end{tabular}




\section{Appendix R}

Gangakhedkar, G., \& Monteiro, J. (2019). A prospective randomized double-blind study to compare the early recovery profiles of desflurane and sevoflurane in patients undergoing laparoscopic cholecystectomy. Journal of Anaesthesiology Clinical Pharmacology, 35(1), 53-57. https://doiorg.ric.idm.oclc.org/10.4103/joacp.JOACP_375_17

\begin{tabular}{|c|c|c|c|c|}
\hline & Question & Yes & $\begin{array}{l}\text { Can't } \\
\text { Tell }\end{array}$ & No \\
\hline 1 & $\begin{array}{l}\text { Did the trial address a clearly focused issue? This } \\
\text { randomized double-blind study compared the recovery } \\
\text { profiles of desflurane and sevoflurane in patients } \\
\text { undergoing laparoscopic cholecystectomy. }\end{array}$ & $\mathrm{X}$ & & \\
\hline 2 & $\begin{array}{l}\text { Was the assignment of patients to treatments } \\
\text { randomized? Yes, using a computer generated table, } \\
\text { patients were randomized into two groups receiving either } \\
\text { sevoflurane or desflurane for anesthesia. }\end{array}$ & $\mathrm{X}$ & & \\
\hline 3 & $\begin{array}{l}\text { Were all the patients who entered the trial properly } \\
\text { accounted for at its conclusion? The article did not } \\
\text { discuss whether all participants finished the study, }\end{array}$ & & $\mathrm{X}$ & \\
\hline 4 & $\begin{array}{l}\text { Were patients, health workers and study personnel } \\
\text { 'blind' to treatment? The study was double blinded. } \\
\text { Due do the nature of the anesthetic, we can assume } \\
\text { anesthesia providers were not blinded. }\end{array}$ & & $X$ & \\
\hline 5 & $\begin{array}{l}\text { Were the groups similar at the start of the trial? Yes, } \\
\text { the baseline characteristics of patients including age, sex, } \\
\text { body mass index, and ASA classification were comparable } \\
\text { in both groups. }\end{array}$ & $\mathrm{X}$ & & \\
\hline 6 & $\begin{array}{l}\text { Aside from the experimental intervention, were the } \\
\text { groups treated equally? Patients were all monitored the } \\
\text { same and received similar doses of medication based on } \\
\text { body weight. All patients underwent laparoscopic } \\
\text { cholecystectomy. }\end{array}$ & $\mathrm{X}$ & & \\
\hline 7 & $\begin{array}{l}\text { How large was the treatment effect? The mean } \\
\text { modified Aldrete score was significantly higher at } \\
\text { extubation in the desflurane group }(7.07) \text { compared to the } \\
\text { sevoflurane group }(6 .), \mathrm{p}<0.001 \text {. The modified Aldrete } \\
\text { scores remained significantly higher in the desflurane } \\
\text { group at } 1,3 \text {, and } 5 \text { minutes postextubation }(8.2 \text { vs } 6.5 \text {, } \\
\mathrm{p}<0.001 ; 8.8 \text { vs } 7.4, \mathrm{p}<0.001 ; 9.0 \text { vs } 8.2, \mathrm{p}=0.036)\end{array}$ & $X$ & & \\
\hline 8 & $\begin{array}{l}\text { How precise was the estimate of the treatment effect? } \\
\text { The power or confidence interval are not discussed in this } \\
\text { article. }\end{array}$ & & $X$ & \\
\hline
\end{tabular}




\begin{tabular}{|c|c|c|c|}
\hline 9 & $\begin{array}{l}\text { Can the results be applied in your context? (or to the } \\
\text { local population?) The results can be applied in this } \\
\text { systematic review. }\end{array}$ & $\mathrm{X}$ & \\
\hline 10 & $\begin{array}{l}\text { Were all clinically important outcomes considered? } \\
\text { Yes, the modified Aldrete score was used which takes into } \\
\text { consideration moving extremities on command, breathing, } \\
\text { and consciousness. The study also examined Bispectral } \\
\text { index strip (BIS) to monitor depth of anesthesia even after } \\
\text { anesthetic gas is turned off and after extubation. }\end{array}$ & $\mathrm{X}$ & \\
\hline 11 & $\begin{array}{l}\text { Are the benefits worth the harms and costs? According } \\
\text { to this study there was no financial support or } \\
\text { sponshorship. Costs are not discussed, nor is any harm }\end{array}$ & & $X$ \\
\hline
\end{tabular}

\section{Appendix S}




\begin{tabular}{|c|c|c|c|c|}
\hline Authors & $\begin{array}{l}\text { Procedure/Type } \\
\text { of surgery }\end{array}$ & Recovery Scale Used & $\begin{array}{l}\text { Time to } \\
\text { recovery } \\
\text { Sevoflurane } \\
\text { (minutes) } \\
\end{array}$ & $\begin{array}{l}\text { Time to } \\
\text { recovery } \\
\text { Desflurane } \\
\text { (minutes) }\end{array}$ \\
\hline $\begin{array}{l}\text { Valasareddy } \\
\text { et al. (2018) }\end{array}$ & $\begin{array}{l}\text { Elective surgical } \\
\text { procedures such } \\
\text { as plastic } \\
\text { surgery, ENT, } \\
\text { and general } \\
\text { surgery }\end{array}$ & $\begin{array}{l}\text { Eye opening on } \\
\text { verbal command: } \\
\text { MAS of } 10 \text { : }\end{array}$ & 8.96 & 5.17 \\
\hline $\begin{array}{l}\text { Sezen \& } \\
\text { Bombaci } \\
(2018)\end{array}$ & $\begin{array}{l}\text { Lower } \\
\text { abdominal } \\
\text { surgery }\end{array}$ & $\begin{array}{l}\text { Eye opening on } \\
\text { verbal command: } \\
\text { MAS of 9: }\end{array}$ & $\begin{array}{l}6.3 \\
15\end{array}$ & $\begin{array}{l}5.80 \\
10\end{array}$ \\
\hline $\begin{array}{l}\text { Pakpirom et } \\
\text { al. }(2015)\end{array}$ & $\begin{array}{l}\text { Non-emergency } \\
\text { surgeries such as } \\
\text { abdominal, } \\
\text { laparoscopic, } \\
\text { neck and throat, } \\
\text { and kidney }\end{array}$ & $\begin{array}{l}\text { Eye opening: } \\
\text { Following } \\
\text { commands: } \\
\text { Length of PACU } \\
\text { stay: }\end{array}$ & $\begin{array}{l}9.6 \\
11.2 \\
49.4\end{array}$ & $\begin{array}{l}7.5 \\
9.0 \\
50.1\end{array}$ \\
\hline $\begin{array}{l}\text { McKay et al. } \\
(2016)\end{array}$ & $\begin{array}{l}\text { Surgery 2-3 } \\
\text { hours in length } \\
\text { requiring } \\
\text { endotracheal } \\
\text { tube and } \\
\text { paralysis }\end{array}$ & $\begin{array}{l}\text { Time from anesthesia } \\
\text { discontinuation to } \\
\text { first appropriate } \\
\text { response: } \\
\text { Time from anesthesia } \\
\text { discontinuation to } \\
\text { first ability to } \\
\text { swallow: } \\
\text { Time from first } \\
\text { response to first } \\
\text { ability to swallow: }\end{array}$ & 6 & 2 \\
\hline
\end{tabular}




\begin{tabular}{|l|l|l|l|l|}
\hline $\begin{array}{l}\text { Gökçek et al., } \\
\text { (2016) }\end{array}$ & $\begin{array}{l}\text { Intracranial } \\
\text { surgery }\end{array}$ & $\begin{array}{l}\text { Time to pull with } \\
\text { painful stimulus: }\end{array}$ & 7.7 & 4.8 \\
\hline $\begin{array}{l}\text { Gas score 9-10: } \\
\text { \& Monteiro } \\
\text { (2019) }\end{array}$ & $\begin{array}{l}\text { Laparoscopic } \\
\text { cholecystectomy }\end{array}$ & Eye opening: & 10.1 & 15.8 \\
\hline
\end{tabular}

